\title{
Assessing Land Cover Transformation for Urban Environmental Sustainability through Satellite Sensing
}

\author{
Syed Atif Bokhari ${ }^{1}$, Zafeer Saqib ${ }^{2}$, Sarah Amir ${ }^{3}$, Salman Naseer ${ }^{4}{ }^{(}$, Muhammad Shafiq $^{5, *}{ }^{\circ}$, Amjad Ali $^{6}$, \\ Muhammad Zaman-ul-Haq ${ }^{7}$, Azeem Irshad ${ }^{8} \mathbb{C}$ and Habib Hamam $9,10,11,12 \mathbb{B}$
}

Citation: Bokhari, S.A.; Saqib, Z.; Amir, S.; Naseer, S.; Shafiq, M.; Ali, A.; Zaman-ul-Haq, M.; Irshad, A.; Hamam, H. Assessing Land Cover Transformation for Urban Environmental Sustainability through Satellite Sensing. Sustainability 2022, 14, 2810. https://doi.org/10.3390/su14052810

Academic Editors:

Agnieszka Dawidowicz and Agnieszka Trystuła

Received: 13 January 2022

Accepted: 25 February 2022

Published: 28 February 2022

Publisher's Note: MDPI stays neutral with regard to jurisdictional claims in published maps and institutional affiliations.

Copyright: (c) 2022 by the authors. Licensee MDPI, Basel, Switzerland. This article is an open access article distributed under the terms and conditions of the Creative Commons Attribution (CC BY) license (https:// creativecommons.org/licenses/by/ $4.0 /)$.
1 Department of Geography, Government Graduate College, Asghar Mall, Rawalpindi 46000, Pakistan; dr.syedatifbokhari@gpgcam.edu.pk

2 GIS and Eco-Informatics Laboratory, Department of Environmental Science, International Islamic University, Sector H-10, Islamabad 44000, Pakistan; zafeer@iiu.edu.pk

3 Department of Environmental Science, Female Campus, International Islamic University, Sector H-10, Islamabad 44000, Pakistan; sarah.amir@iiu.edu.pk

4 Department of Information Technology, University of the Punjab Gujranwala Campus, Gujranwala 52250, Pakistan; salman@pugc.edu.pk

5 Department of Information and Communication Engineering, Yeungnam University, Gyeongsan 38541, Korea

6 Pakistan Space and Upper Atmosphere Research Commission (SUPARCO), Karachi 75270, Pakistan; amjadalee65@yahoo.com

7 Department of Environmental Science, International Islamic University, Islamabad 44000, Pakistan; zaman@iiu.edu.pk

8 Department of Computer Science and Software Engineering, International Islamic University, Islamabad 44000, Pakistan; irshadazeem2@gmail.com

9 Faculty of Engineering, Uni de Moncton, Moncton, NB E1A3E9, Canada; habib.hamam@umoncton.ca

10 International Institute of Technology and Management, Commune d'Akanda, Libreville BP1989, Gabon

11 School of Electrical Engineering, Department of Electrical and Electronic Engineering Science, University of Johannesburg, Johannesburg 2006, South Africa

12 Spectrum of Knowledge Production \& Skills Development, Sfax 3027, Tunisia

* Correspondence: shafiq@ynu.ac.kr; Tel.: +82-10-7145-4060

\begin{abstract}
Rapid urbanization in Pakistan is triggering regulated and unregulated land cover changes in planned and semiplanned urban areas. The key objective of this study is to assess the spatialtemporal fluctuations in the land use/land cover (LULC) transformations in planned (Islamabad) and semiplanned (Rawalpindi) urban areas over the last forty years (1976-2016). The study focuses on the orientation of LULC modifications and analyzes concomitant impacts on urban environmental sustainability. Therefore, remotely sensed data were retrieved and processed through Google Earth Engine (GEE) by applying supervised classifier algorithms on each of the five chosen Landsat images. The trajectory of LULC changes for each of the four periods 1976-1988, 1988-1995, 1995-2006 and 2006-2016 was critically scrutinized. The observations revealed massive physical expansions and LULC convergences during these timeframes. The proportionate share of built-up surfaces in this contextual setting substantially stretched from $0.83 \%$ in 1976 to $23.23 \%$ in 2016 , while the shares of cropland and shrubberies significantly reduced. The orientation and magnitude of such changes were observed asymmetrically in the adjoining urban settlements. The assessments formulate that availability of land for urban growth, urban planning and regulatory control significantly determines the speed, scale and orientation of urbanization in planned and semiplanned areas. The study substantiates the notions that the efficient use of cost-effective remotely sensed data offers a pragmatic and reliable tool for assessing, evaluating and monitoring urban land resources. The inferences and insights are relevant for urban and regional planners as well as for other scientific communities.
\end{abstract}

Keywords: environmental sustainability; land cover; hyperactive urbanization; remote sensing; geographic information system 


\section{Introduction}

Land use/land cover (LULC) changes influence the structure, functioning and capacities of natural ecosystems [1-4]. The resultant modifications in land cover produce indelible imprints on the natural and social environments at the local level [2,5]. Therefore, assessments based upon land cover transformations are incumbent to adjust the orientation of human interventions in the terrestrial environment [5].

The process of LULC modifications started when human beings tried to regulate their environment [6]. The associated sociocultural transformations, such as population growth, societal organization and increased focus on provisioning for survival, gave rise to the phenomenon of permanent settlement. Subsequent growth and sprawl in these settlements triggered LULC changes [7]. The ensuing land cover transformations are exerting pressures on the ecological balance $[8,9]$ and proving stressful for the natural and social environments.

The consequential impacts of urbanization are more apparent in developing countries $[10,11]$. The process of urbanization is escalating in the South Asian region [12]. The pace and scale of urbanization in Pakistan has also gained momentum [13]. The process is rooted in natural population growth [14] and rural-to-urban migration in this country [15]. Migration from rural to urban areas in Pakistan is attributable to the peculiar historic [16,17], social [18], economic [19], environmental [20] and geostrategic dynamics of this region. However, urbanization in Pakistan [21] is skewed towards large urban settlements [22]. The inclinations are embedded in urbancentric economic growth, industrialization and enhanced focus on infrastructural developments in big urban areas [2,9]. Consequently, the inflow of migrants is straining the land and environmental resources in such contextual settings [23,24].

The accompanying demands for land resources are exerting pressures for planned/ unplanned urban expansion and concomitant modifications in land cover of urban areas. The ensuing imprints are visible in the form of uncontrolled urban sprawl and vertical growth in the city structures. Therefore, the keenness for assessing LULC changes in urban areas is gathering momentum. This scenario entails identification of the factors responsible for such intended and unintended LULC transformations. It also requires the evaluation of the speed, scale and orientations of such transformations in the urban areas. To attain this purpose, precision in measurement is obligatory for realistic inferences [25]. Contemporary advances in remote sensing (RS) and Geographic Information System (GIS) offer reliable tools for illustrating and spotting spatial-temporal transformations in the LULC [25,26]. Moreover, the digital archives of remotely sensed data also allow the quantification of such changes in the LULC [27]. These assessments are incumbent for rational policy making to mitigate the impacts of urbanization $[26,28]$ through land use planning and assessment $[27,29]$. The regulatory interventions based on quantitative assessments would further ensure the sustainable use of urban environmental resources [30,31].

The current investigation focuses on the LULC changes in Islamabad and Rawalpindi. These adjoining urban centers are called twin cities. However, their distinctive policy, planning and management frameworks concerning land resources are inherently different from each other. The study area thus offers an appropriate contextual setting, namely, both planned and semiplanned urban structures, for deciphering the impacts of urbanization on the LULC transformations in Pakistan.

To this end, similar investigations were carried out by Hassan et al. [32] and Butt et al. [33] in this area. Whereas the former study focuses on the LULC changes in Islamabad, the latter tries to comprehend the impacts of such transformations on the water reservoir of Simly dam (Islamabad). The proposed study is different from the above-mentioned research, as it simultaneously assesses LULC modifications in both Islamabad and Rawalpindi. The comparative assessment is vitally required but not available in the context of this [24]. In addition, the study carried out by [34] is quite relevant. However, it only focuses on recent LULC changes (2017-2019) in Islamabad. Contrary to this, the proposed study takes into account long-term temporal data (1976-2016) for assessments. 
The findings of the study authenticate the notion that urban centers in the developing world are witnessing massive physical expansions and LULC convergences. It transpires that the built-up surfaces are stretching at the cost of blue-green infrastructures in urban areas. The orientations and magnitude of these transformations are analyzed, and a marked lack of symmetry is observed in the planned and semiplanned urban centers. This study formulates that urban planning, societal pressures and integrated regulatory oversight symptomatically determine urban environmental sustainability. The study also authenticates the robustness of remotely sensed data as a cost-effective and reliable mechanism for ensuring integrated management of urban land resources.

The specific objectives of this study are primarily to compare the impacts of urbanization on the LULC changes in the study area from 1976 to 2016 and to quantify the orientations of changes in the selected LULC categories for a similar time period (1976-2016).

The subsequent section deals with the methodological framework of this study. The critical findings are condensed and portrayed Section 3 which is exclusively concerned with results. In Section 4, the plausible causations and resultant ramifications of observed findings are discussed. The conclusions are drawn in the last section.

\section{Methods}

\subsection{The Study Area}

The current investigation was carried out in the urban and suburban areas of the twin cities, namely, Islamabad and Rawalpindi. The study area stretches from $72^{\circ} 49^{\prime \prime} \mathrm{E}$ to $73^{\circ} 17^{\prime \prime} \mathrm{E}$ and from $33^{\circ} 26^{\prime \prime} \mathrm{N}$ to $33^{\circ} 45^{\prime \prime} \mathrm{N}$ (Figure 1). It is located in the southern foothill areas of the Himalayan ranges. This dissected and undulating land surface constitutes the northwestern fringes of the Potohar Plateau. The average elevation of Islamabad from sea level is higher compared to that of Rawalpindi [35].

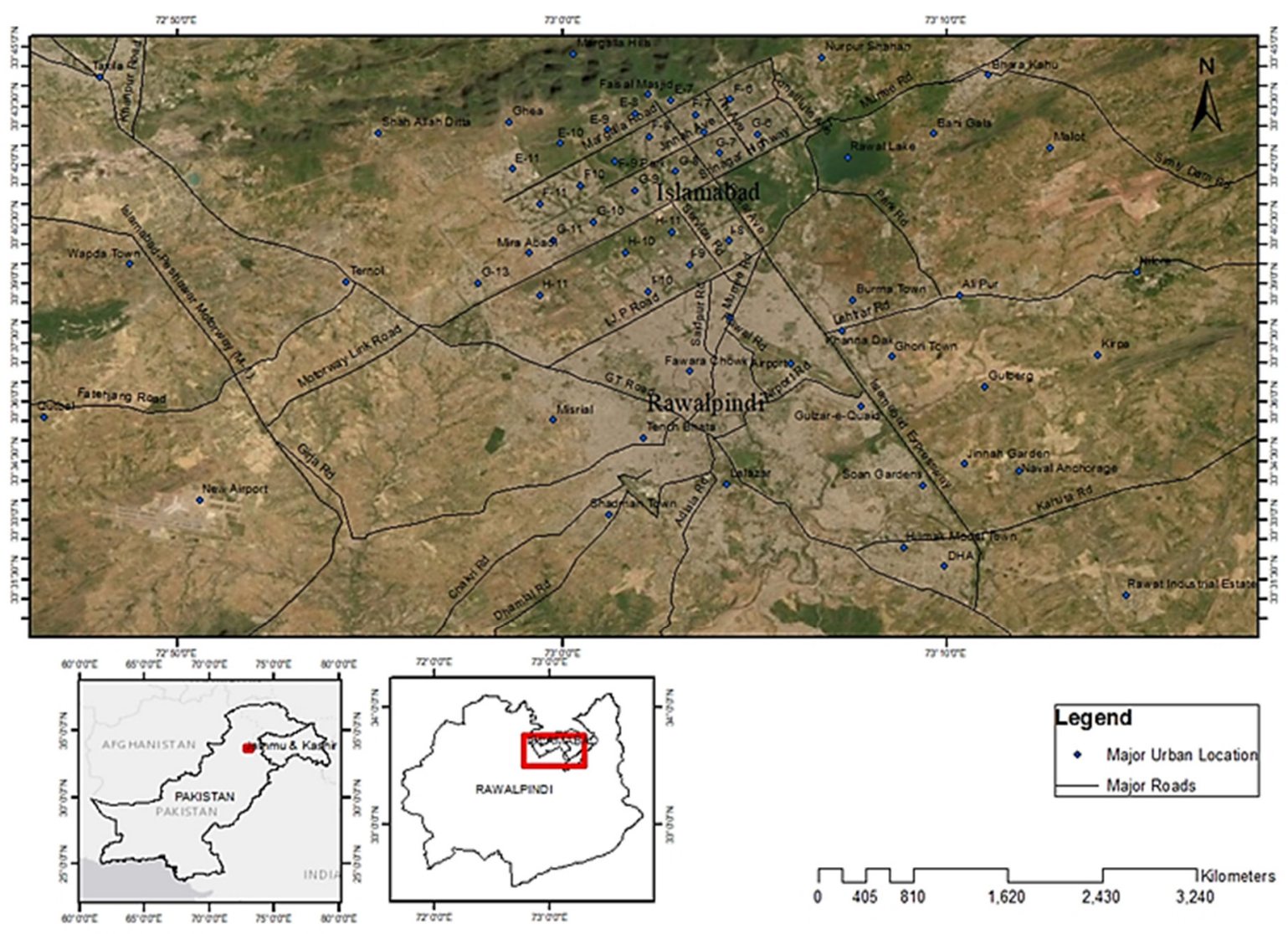

Figure 1. Study area map of Islamabad and Rawalpindi. 
The climate of this geographical region is significantly influenced by the prevailing monsoon and western depressions [36]. Köppen et al. [37] classified this area in the temperate climatic zone with dry winters and hot summers (CWa). It receives maximum precipitation due to summer monsoon winds [38], while the western depressions in the winter also cause sufficient precipitation for the rain-fed vegetation growth [39]. The findings (Figure 2) succinctly portray the average monthly oscillations in temperature and precipitation.
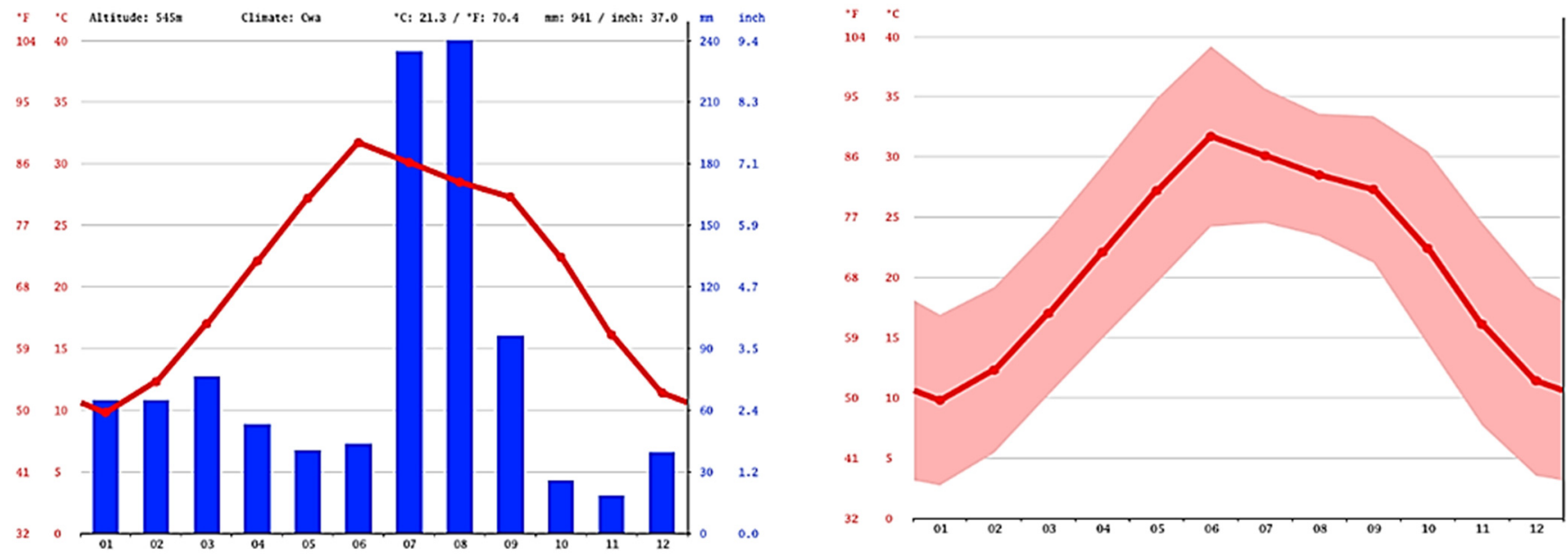

\begin{tabular}{l|c|c|c|c|c|c|c|c|c|c|c|c|} 
& January & February & March & April & May & June & July & August & September & October & November & December \\
\hline Avg. Temperature $\left({ }^{\circ} \mathrm{C}\right)$ & 9.8 & 12.5 & 17.3 & 22.6 & 27.6 & 32 & 30.3 & 28.6 & 27.6 & 22.7 & 16.2 & 11.3 \\
\hline Min. Temperature $\left({ }^{\circ} \mathrm{C}\right)$ & 2.7 & 5.5 & 10.4 & 15.3 & 19.9 & 24.5 & 24.8 & 23.6 & 21.6 & 14.5 & 7.5 & 3.3 \\
\hline Max. Temperature $\left({ }^{\circ} \mathrm{C}\right)$ & 17 & 19.5 & 24.2 & 29.9 & 35.4 & 39.5 & 35.8 & 33.7 & 33.6 & 30.9 & 25 & 19.3 \\
\hline Precipitation /Rainfall $(\mathrm{mm})$ & 58 & 56 & 68 & 44 & \multicolumn{1}{c|}{38} & 37 & 237 & 238 & 92 & 23 & 16 & 36
\end{tabular}

Figure 2. Month-wise weather and climatic data of Islamabad and Rawalpindi. (Source: https: //en.climate-data.org; Accessed on 16 August 2018).

The planned development of Islamabad started in 1959 [40]. It was premeditated to serve as the new capital of Pakistan [23,24], while the older city of Rawalpindi [41] is a semiplanned urban settlement $[23,24]$ and serves as the central place for the adjoining areas. Economic, social and geostrategic factors stimulated rural-to-urban area migration in this region. As a result, the human population in these urban settlements has rapidly increased in previous years (Appendix A).

\subsection{Data Acquisition and Assessment Approach}

The data for assessing spatial-temporal conversions in the LULC were retrieved through the Google Earth Engine (GEE). The GEE is a cloud-computing platform that offers high-resolution aerial imagery without financial costs. In addition to this, the working environment in the GEE also facilitates classification and ensures validation. Therefore, the technique was deployed and assessments were made by improvising codes in the GEE platform (Google Earth Engine, 2012. URL: https://earthengine.google.com; Accessed on 1 May 2016) [42]. The evaluations pertaining to LULC changes were formulated by deploying supervised classifier algorithms on each of the five (05) chosen Landsat images, which covered a period of forty years (1976-2016).

The limitations of field data hinder LULC classifications based on archived images through training and validation sampling techniques [43]. However, a context-based selection of LULC classes, in conjunction with a sizeable sample, yields meaningful and reliable assessments [44]. Thus, the most recent image was relied upon for LULC stratification. 
For this purpose, 500 observations were made through field survey. In the next stage, the stratified random sampling approach was deployed to determine the number of samples for each of the selected classes from different time spans $[45,46]$. Subsequently, band combinations and image normalization techniques were applied for estimating the chronology of transformations in the observed LULC categories [47].

The salient characteristics of the images relied upon for the assessments have been condensed (Table 1). The images were accessed on 01-05-16, and bands 1, 2, 3, 4, 5 and 7 were adjudged related to the study. WRS-1 161-37 path/rows and WRS-2 150/37 covered the whole study area. Noises in the satellite images caused distortions, thus leading to misrepresentations of the findings. These anomalies were erased according to the Landsat 8 quality assessment band criteria [48,49]. The corrections were weighed at four levels, namely, "not determined" (algorithm did not regulate the status of this condition), "no" (0-33\% confidence level), "maybe" (34-66\% confidence level) and "yes" (67-100\% confidence level). This process was performed to ensure the precision and accuracy of the findings.

Table 1. Characteristics and references of satellite images used.

\begin{tabular}{cccccc}
\hline Year & Satellite Sensor & $\begin{array}{c}\text { Spatial } \\
\text { Resolution }\end{array}$ & AQ Data & $\begin{array}{c}\text { Worldwide } \\
\text { Reference System } \\
\text { (WAR) }\end{array}$ & Source \\
\hline 1976 & Landsat 2 MSS & $60 \mathrm{~m} \times 60 \mathrm{~m}$ & $1976-10-19$ & WRS 1: 161/37 & USGS imagery \\
1988 & Landsat 5 TM & $30 \mathrm{~m} \times 30 \mathrm{~m}$ & $1988-05-04$ & WRS 2: 150/37 & access through the \\
1995 & Landsat 5 TM & $30 \mathrm{~m} \times 30 \mathrm{~m}$ & $1995-11-16$ & WRS 2: 150/37 & GEE platform \\
2005 & Landsat 7 ETM+ & $30 \mathrm{~m} \times 30 \mathrm{~m}$ & $2005-09-16$ & WRS 2: 150/37 & WRS 2: 150/37 \\
2016 & Landsat 7 ETM+ & $30 \mathrm{~m} \times 30 \mathrm{~m}$ & $2016-05-01$ & & \\
\hline
\end{tabular}

\subsection{Extraction of LULC Classes}

The satellite images were classified by deploying the classification and regression tree (CART)-based mechanism. The CART is a nonparametric machine-learning classifier [50]. The reliance on remotely sensed images for LULC mapping through machine-learningbased algorithms is gaining recognition [51]. It is a fast-performing, robust technique [52] that provides highly accurate LULC classification by using images collected through remote sensing [53]. Thus, the CART classifier was deployed for extracting features and mapping.

The level 1 classification of this scheme was implemented for assessing LULC changes (Table 2). For this purpose, field observations from 500 sampling sites were made with the support of Global Positioning System (GPS), while a total of 1835 sample plots were manually observed on freely available higher-resolution images in the GEE (Figure 3). The training data were retrieved through the visual inspection of the selected images. The scrutiny enabled us to identify the Landsat pixels that were entirely made up of any selected LULC class (Table 2).

Table 2. The interpretation of LULC classes in the study area.

\begin{tabular}{|c|c|c|}
\hline Sr. No & Class (Level-1) & Description (Level 2) \\
\hline 1 & Cropland & Mostly rain-fed cropping. \\
\hline 2 & Grasses & $\begin{array}{c}\text { Natural/manmade grass covers and herbaceous } \\
\text { surfaces. }\end{array}$ \\
\hline 3 & Tree/Forest & $\begin{array}{l}\text { The street and park trees, the woodland in the urban } \\
\text { and peri-urban fringes of study area. }\end{array}$ \\
\hline 4 & Shrubs/Tall herbs & Vegetation cover dominated by shrubs/tall herbs. \\
\hline 5 & Bare soil/rocks & $\begin{array}{l}\text { Barren lands with extremely low vegetative } \\
\text { coverage. }\end{array}$ \\
\hline 6 & Built-up & The continuous and discontinuous built-up fabric. \\
\hline 7 & Water & $\begin{array}{c}\text { The water bodies and water courses in the study } \\
\text { area. }\end{array}$ \\
\hline
\end{tabular}



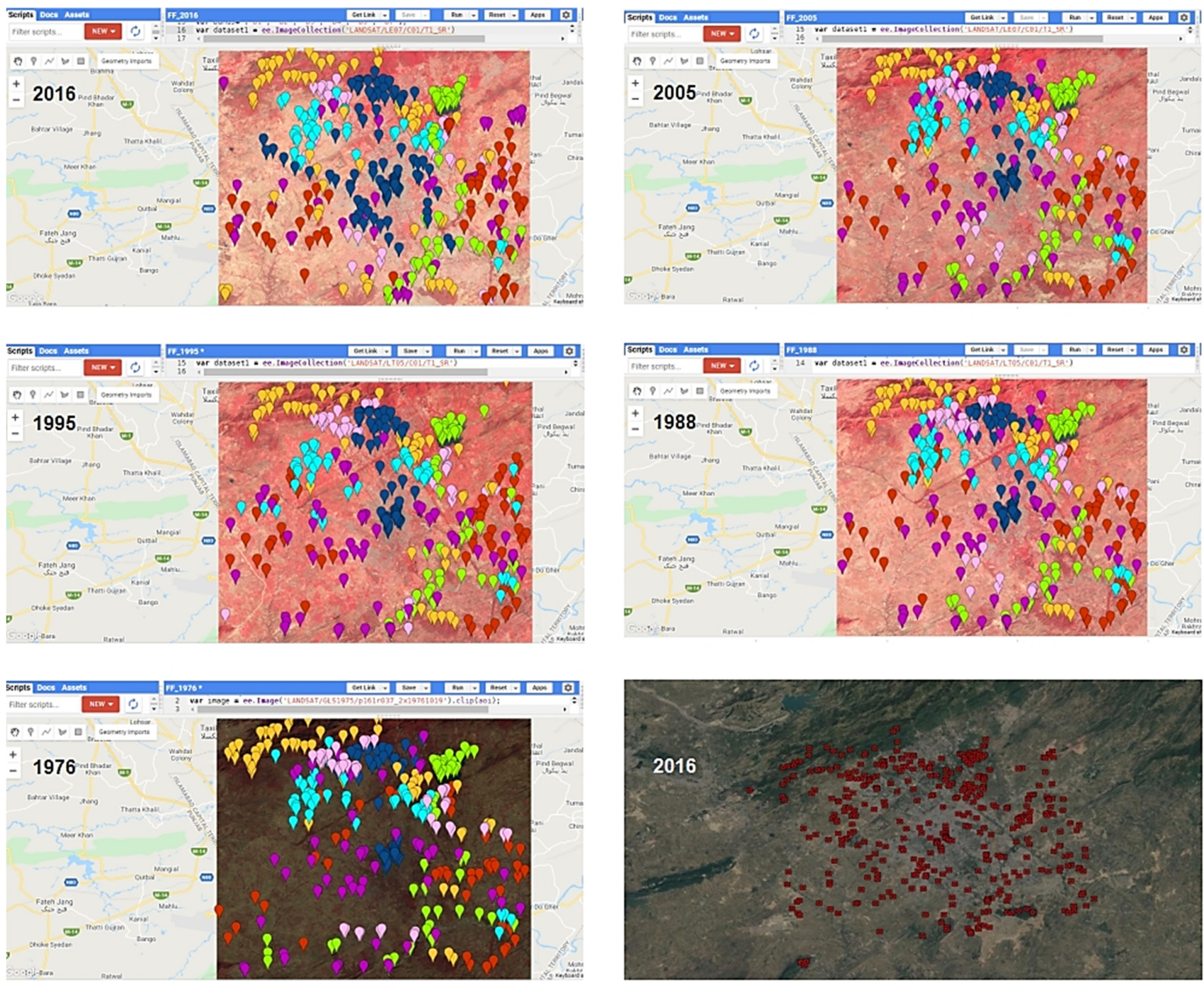

Figure 3. GEE- and field-survey-based sampling.

For model validation, $80 \%$ of the sample points from each category were randomly selected to use as training data, while the remaining $20 \%$ of the sample points were used as a validation dataset. Shao and Lunetta [54], Shetty [42] and Magidi et al. [55] also deployed a similar nature of mechanism for inferences and assessments. The training and validation samples of each year were separately uploaded in the GEE through the Google Fusion Tables (GFT). For feature extractions and mapping, supervised [56,57] as well as unsupervised $[58,59]$ classification techniques were relied upon (Figure 4).

\subsection{Transition Analysis of LULC}

Transition analysis was also carried out for interpreting the impacts of urbanization on urban structure and prevailing environment. For this purpose, the LULC transformations among the classes were quantified for the selected time intervals from 1976 to 2016 (Table 2). The findings were relied upon for deciphering spatial-temporal variations in the selected LULC classes. The process was accomplished in R Software (version 3.4.4). The flexible environment of this tool enables us to perform statistical procedures by improvising codes. The assessments pertaining to interclass transitions for mapping were performed in R through the "lulcc" package [60]. The assessments were based on the following equation [61,62]:

$$
\text { Rate }=\left(\frac{1}{t_{2}+t_{1}}\right) \cdot \ln \left(\frac{A i_{2}}{A i_{1}}\right)
$$


where $A i_{1}$ accounts for the cover of class $i$ at an initial time $t_{1}$ and $A i_{2}$ denotes the cover of class $i$ at a later time $t_{2}$.

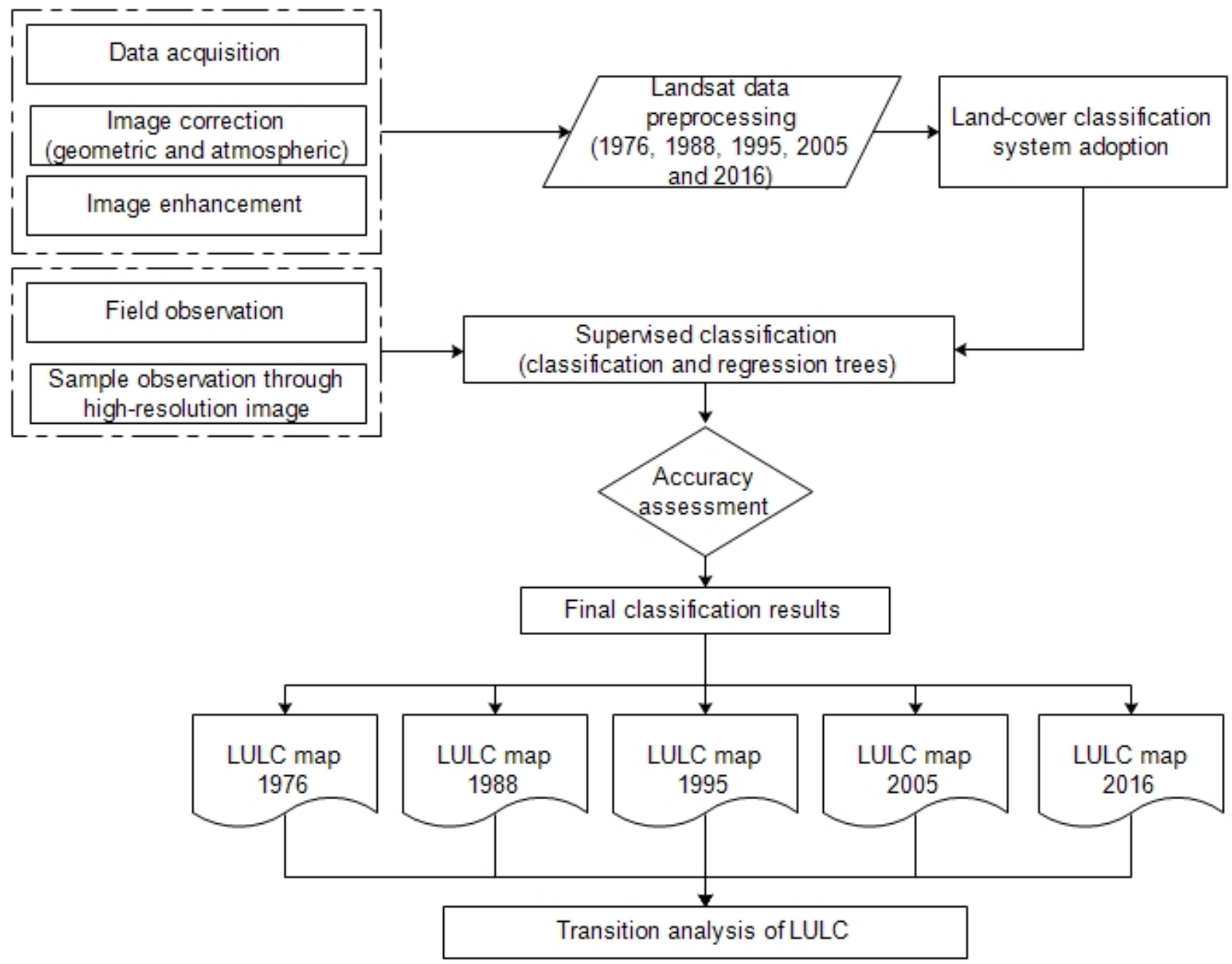

Figure 4. Schematic representation of procedures adopted for the LULC analysis.

\section{Results}

\subsection{Accuracy Assessments}

Accuracy assessment in image-based classifications is required for ensuring precision [63]. The cross-validation of assessments was performed through the Kappa test. The Kappa coefficient helps us to identify those instances that may have been correctly classified by chance. It focuses on the differences between observed (total) accuracy and random accuracy. Once completed, the LULC maps were examined by adopting standard parameters (https://developers.google.com/earth-engine; Accessed on 1 May 2016) for their positional and thematic accuracy. The overall classification accuracy ranges from $83 \%$ to $92 \%$ (Appendix B).

\subsection{Temporal Variations in the LULC}

The urban expansions and concomitant LULC changes in Islamabad (planned) and Rawalpindi (semiplanned) have different natures of imprints on the land resources. Therefore, quantitative assessments based on temporal variations in the share of selected LULC classes were performed (Table 3). The findings were subsequently relied upon for change detection (Table 4). The assessments enabled the comprehension of the dynamics and the evaluation of the consequential impacts of urbanization on the selected land cover classes for holistic appraisals. 
Table 3. Characteristics and references of satellite images used.

\begin{tabular}{|c|c|c|c|c|c|c|c|c|c|c|}
\hline \multirow{2}{*}{$\begin{array}{c}\text { LULC } \\
\text { Class/Year }\end{array}$} & \multicolumn{2}{|c|}{1976} & \multicolumn{2}{|c|}{1988} & \multicolumn{2}{|c|}{1995} & \multicolumn{2}{|c|}{2005} & \multicolumn{2}{|c|}{2016} \\
\hline & $\mathrm{km}^{2}$ & $\%$ & $\mathrm{~km}^{2}$ & $\%$ & $\mathrm{~km}^{2}$ & $\%$ & $\mathrm{~km}^{2}$ & $\%$ & $\mathrm{~km}^{2}$ & $\%$ \\
\hline Cropland & 600.31 & 55.22 & 579.33 & 53.29 & 694.98 & 63.93 & 629.54 & 57.91 & 355.16 & 32.67 \\
\hline Grasses & 54.83 & 5.04 & 90.52 & 8.33 & 47.62 & 4.38 & 47.68 & 4.39 & 146.66 & 13.49 \\
\hline Trees/Forest & 168.53 & 15.50 & 130.86 & 12.04 & 171.48 & 15.77 & 206.77 & 19.02 & 111.61 & 10.27 \\
\hline $\begin{array}{l}\text { Shrubs/Tall } \\
\text { herbs }\end{array}$ & 228.81 & 21.05 & 212.57 & 19.55 & 105.04 & 9.66 & 74.53 & 6.86 & 96.45 & 8.87 \\
\hline $\begin{array}{c}\text { Bare } \\
\text { soil/rocks }\end{array}$ & 18.02 & 1.66 & 8.66 & 0.80 & 8.39 & 0.77 & 11.12 & 1.02 & 102.43 & 9.42 \\
\hline Built-up & 9.03 & 0.83 & 35.17 & 3.24 & 48.93 & 4.50 & 110.14 & 10.13 & 252.51 & 23.23 \\
\hline Water & 7.63 & 0.70 & 30.05 & 2.76 & 10.72 & 0.99 & 7.38 & 0.68 & 22.35 & 2.06 \\
\hline
\end{tabular}

Table 4. Characteristics and references of satellite images used.

\begin{tabular}{ccccccc}
\hline \multirow{2}{*}{ LULC } & \multicolumn{2}{c}{ 1976-2016 } & \multicolumn{2}{c}{ 1976-2016 } & \multicolumn{2}{c}{ 1976-2016 } \\
\cline { 2 - 7 } Class/Year & \multicolumn{2}{c}{ Loss } & \multicolumn{2}{c}{ Gain } & \multicolumn{2}{c}{ Net Change } \\
\cline { 2 - 7 } & ISB & RWP & ISB & RWP & ISB & RWP \\
\hline Cropland & -186.34 & -127.21 & 49.44 & 28.53 & -136.9 & -98.68 \\
Grasses & -21.85 & -15.47 & 81.89 & 42.41 & 60.04 & 26.94 \\
Trees/Forest & -67.94 & -40.97 & 44.42 & 17.77 & -23.52 & -23.2 \\
Shrubs/Tall & -122.91 & -70.17 & 46.69 & 23.88 & -76.22 & -46.29 \\
herbs & & & & & & \\
Bare & -6.52 & -8.88 & 61.91 & 31.67 & 55.39 & 22.79 \\
soil/rocks & -0.14 & -0.11 & 113.84 & 112.78 & 113.7 & 112.67 \\
Built-up & -0.78 & -0.39 & 8.3 & 6.14 & 7.52 & 5.75 \\
$\quad$ Water & & & & &
\end{tabular}

The most noteworthy growth was detected in the built-up areas (as mentioned in Table 3). We see that this category's share stretched from $0.83 \%$ in 1976 to $23.23 \%$ in 2016. The bare soil/rocks and grasses are the other categories in which marked increases were noted. However, observable shrinkages (in \%) in shares and total areas of cropland and shrubby surfaces were quite significant (Table 3). The cropping areas declined from $55.22 \%$ in 1976 to $32.67 \%$ in 2016 and the shrubs/tall herbs shrank from $21.05 \%$ to $8.87 \%$ during this period. The findings (Table 3 ) indicate noticeable oscillations in the categories of water and trees/forested areas.

\subsection{Spatial Inclinations in LULC Modifications}

The illustrations (Figures 5-9) magnify the spatial-temporal trajectory of reported LULC modifications. Figure 5 portrays that the natural LC in Islamabad was undisturbed in 1976. The built-up area in the city was very limited and sparse. The cropland was still the dominant land cover in Islamabad, being interspersed with hamlets in the vicinity. At this stage, the tree cover was very dense along the Margalla Hills in the north and around Rawal Lake in the east of the city. During the same time period, the agrarian imprints on the LULC of the Rawalpindi city were quite visible (Figure 5). However, the built-up areas were concentrated in and around the central business district (CBD) of the city, i.e., Fawara Chowk, in Rawalpindi.

Figure 6 construes about the ensuing urban densification in the study area. The phenomena caught momentum around the CBD, i.e., Fawara Chowk, in Rawalpindi. The urban expansion during 1976-1988 in Rawalpindi was more inclined towards Islamabad. Figure 6 also depicts the creeping urban sprawl and LULC transformations in Islamabad. The proportion of built-up areas significantly increased during this time in Islamabad. However, the impacts of urbanization and associated LULC changes during 1976-1988 were concentrated around the urban core areas in both urban settlements. The other land cover classes registered no noticeable fluctuations during this time. 


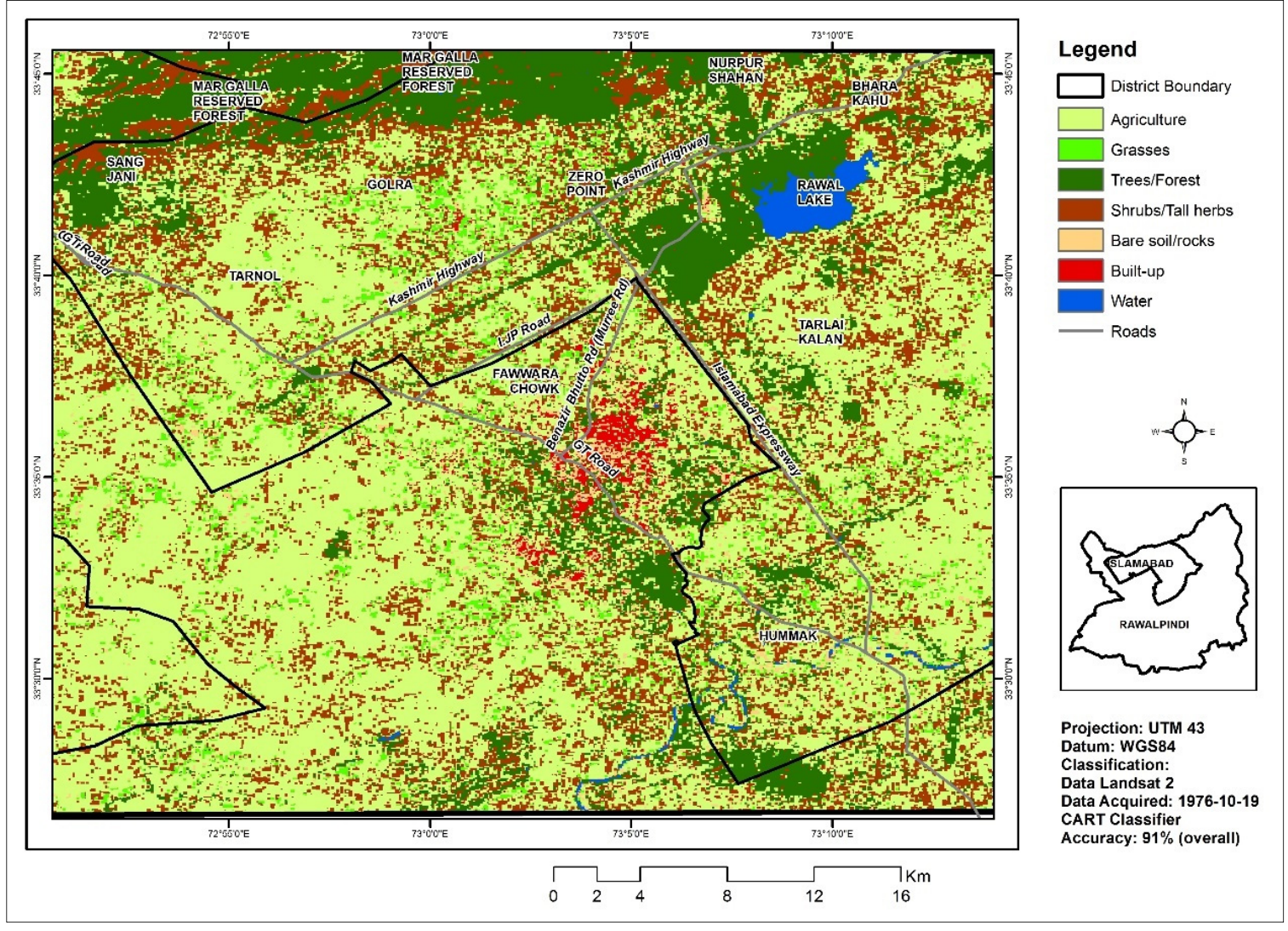

Figure 5. LULC map of year 1976.

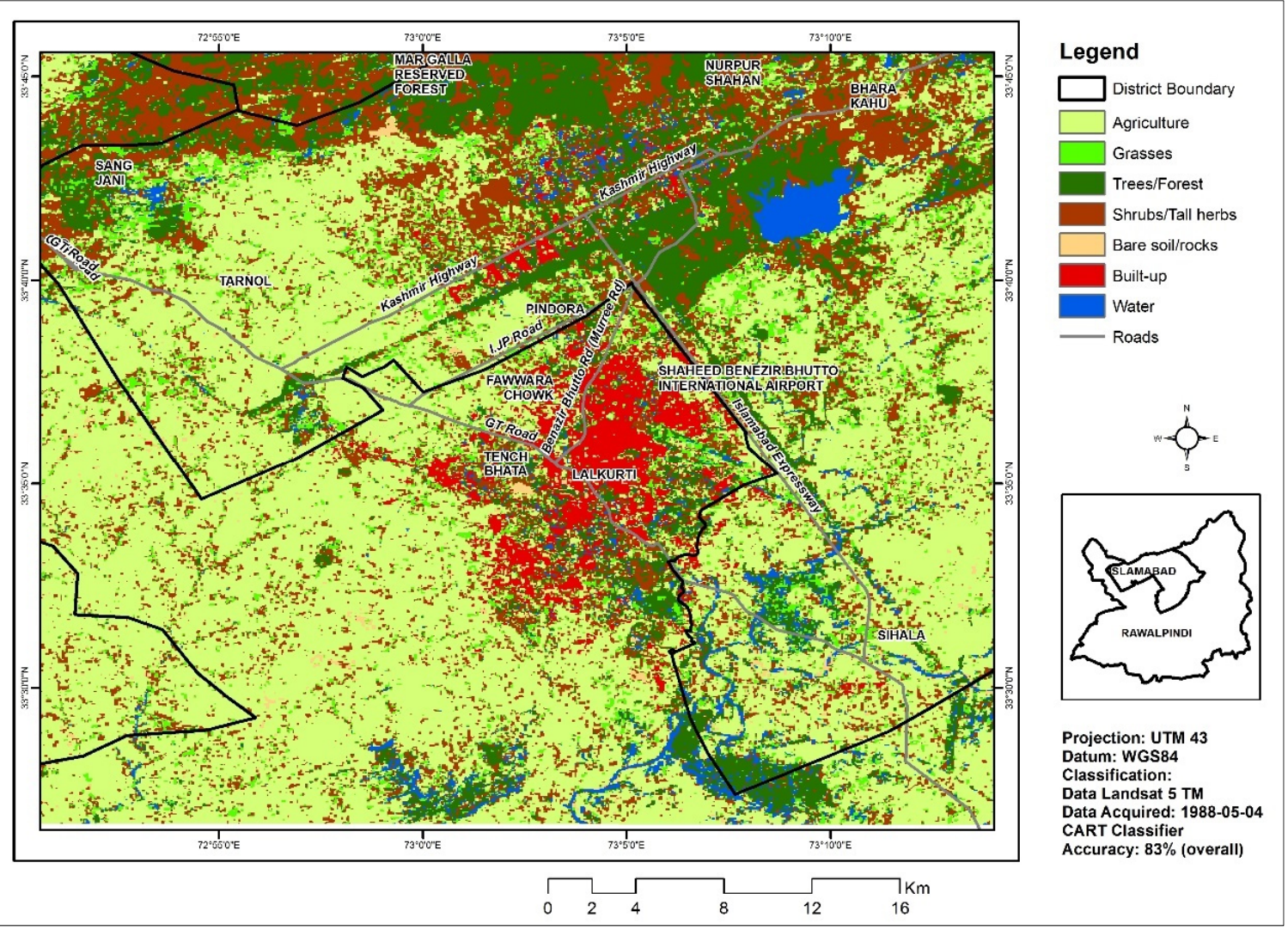

Figure 6. LULC map of year 1988. 


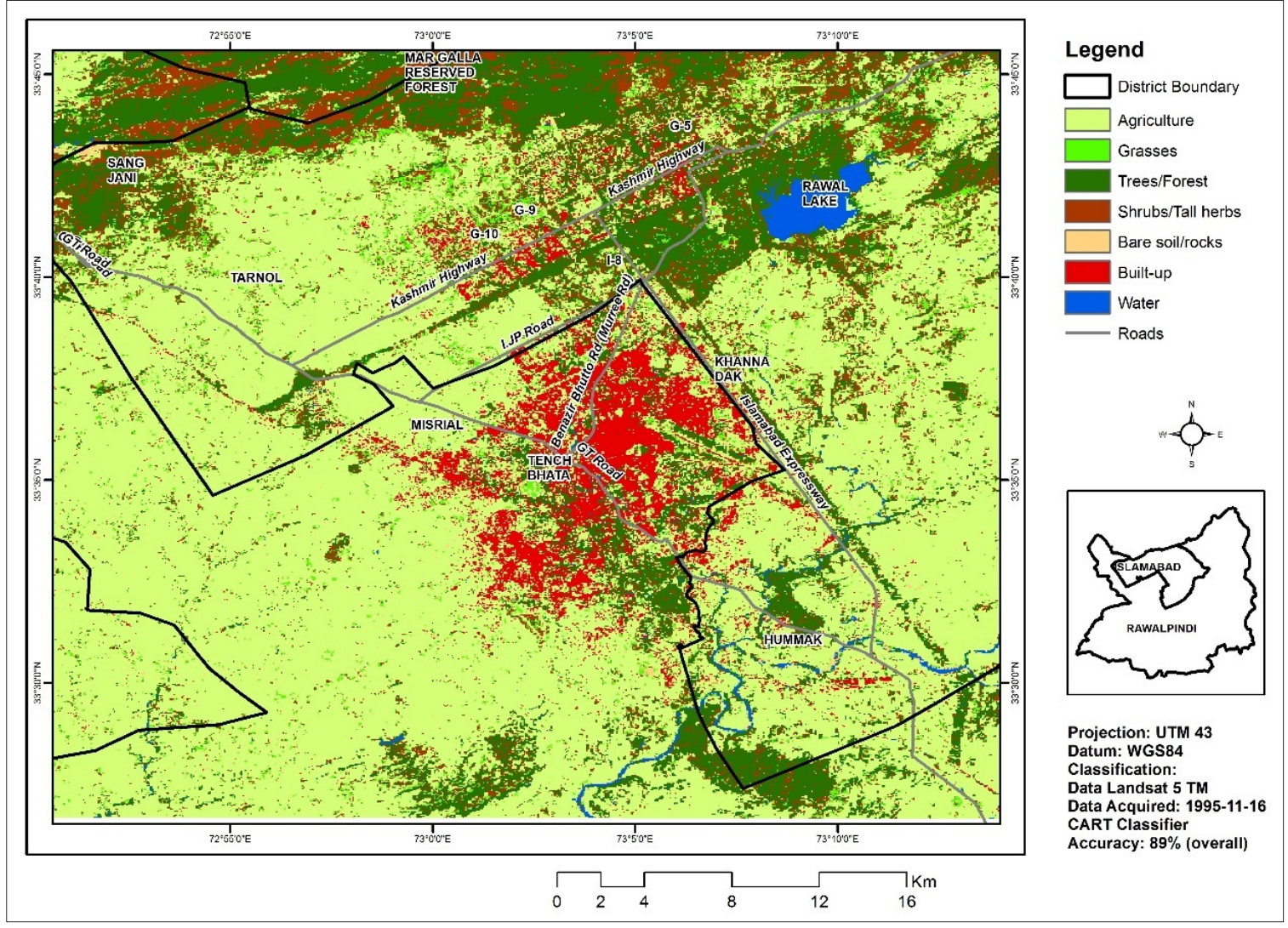

Figure 7. LULC map of year 1995.

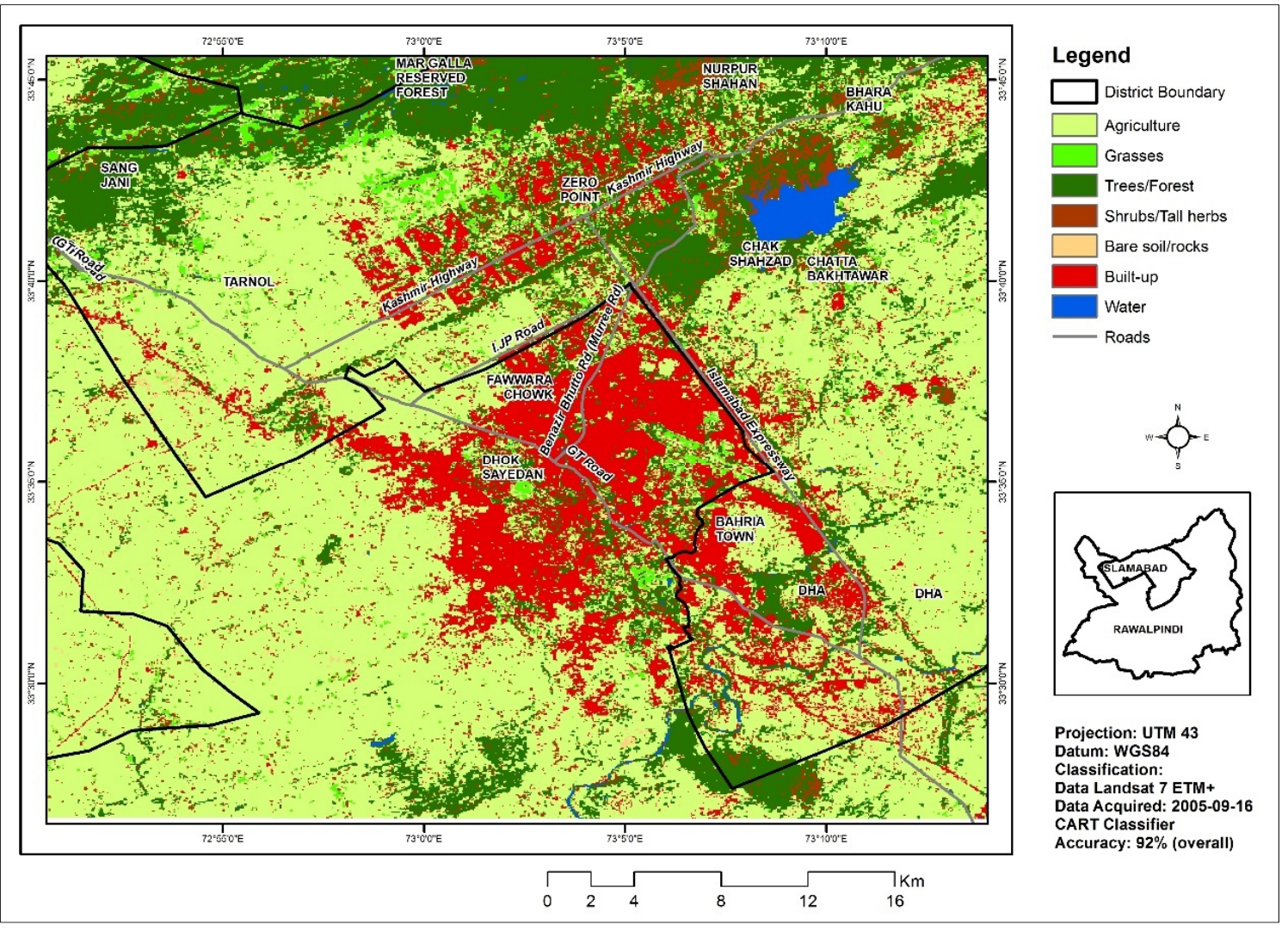

Figure 8. LULC map of year 2005. 


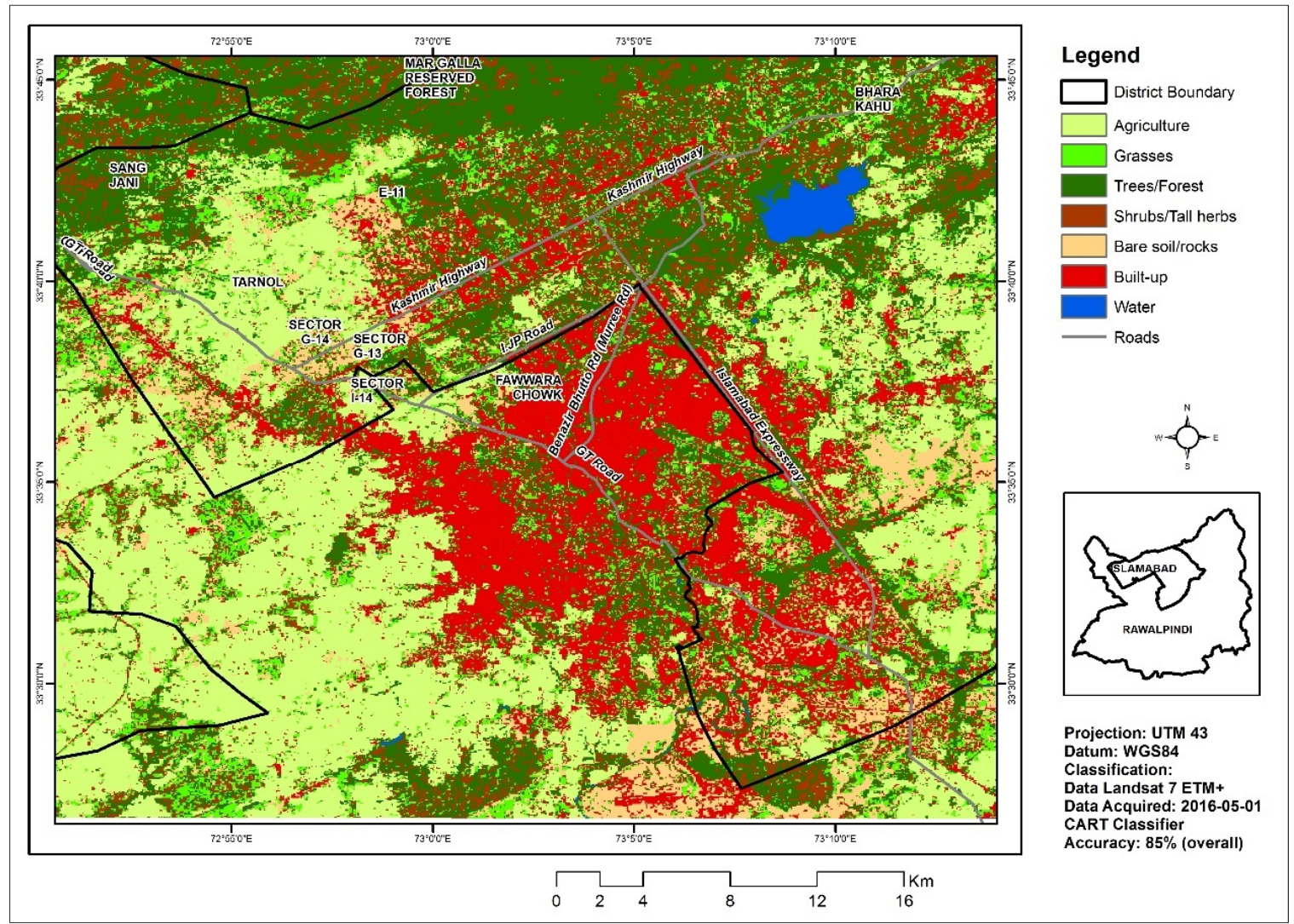

Figure 9. LULC map of year 2016.

Physical expansion of Islamabad gained impetus during 1988-1995 (Figure 7). The focus shifted to fulfill the growing demands from the housing sector. Resultantly, the built-up areas expanded with the development of new residential sectors, such as G-9, G-10, I-8, etc., in Islamabad (Figure 7). During this phase, Islamabad expanded in the southeast with the development of Humak Model Town. Meanwhile, the urban sprawl of Rawalpindi was still inclined towards Islamabad. However, with the horizontal expansions in the physical structure of Rawalpindi, the neighboring unplanned/rural settlements, such as Khanna Dak in the east, Misrial in the west and Tanch Bhata in the south, became the new functional units of the city (Figure 7).

The findings (Table 3) conjecture about the intensifying impacts of urbanization on the LULC transformations in the following time interval: 1995-2005. Figure 8 portrays that the impacts were more pronounced in Islamabad compared to Rawalpindi. However, the transformations were acute in areas which were physically detached from the CBD of Islamabad. Newly planned commuting areas of Islamabad emerged and expanded in the southeast of Rawalpindi during this time. Horizontal expansions were also observed along the Grand Trunk Road (GT Road) in the west, around the eastern periphery of Bara Kahu and in the northern rural hamlet of Nurpur Shahan in Islamabad (Figure 8). During the same time period, the phenomenon of urban densification became more pronounced around the urban core areas in Rawalpindi. During this time (1995-2005), Rawalpindi city expanded up to its southern limits and stretched farther westward up to Dhok Saiyidan.

Urban expansions continued to gain momentum during 2005-2016. Their indelible imprints are visible in the forms of massive urban sprawl (Figure 9) and LULC changes (Table 3). The proportions of built-up areas and bare soil/rock surfaces enlarged during this time period. However, significant reductions in the cropping areas and forested land covers were observed. These types of modifications were mostly observed in the newly developed residential sectors of Islamabad. In addition to this, such convergences were stimulated by unregulated land conversions in the peripheral areas of the capital (Figure 9). Meanwhile, in Rawalpindi, rapid 
urbanization during 2005-2016 exhausted the land resources in and around the urban core areas. In return, the built-up areas were forced either to expand vertically or to spread in the west, the southwest or the southeast directions.

\subsection{The Interclass Transitions}

Assessments were made to ascertain the magnitude of increases or decreases in the share of a specific LULC class (Table 4). The appraisals were relied upon for magnifying the impacts of urbanization on interclass convergences and transitions (Figure 10). In addition to this, the quantitative assessments also enabled us to identify the factors responsible for the observed transformations from 1976 to 2016.

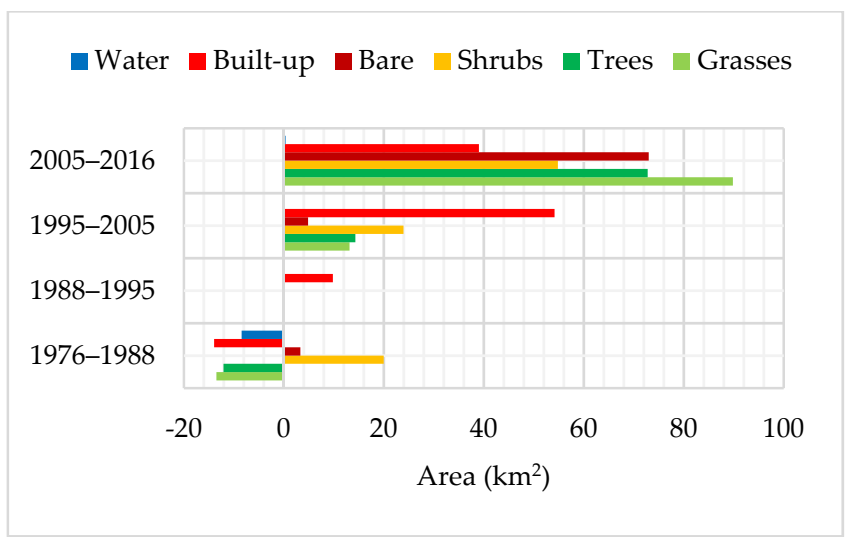

(a) Transition from cropland

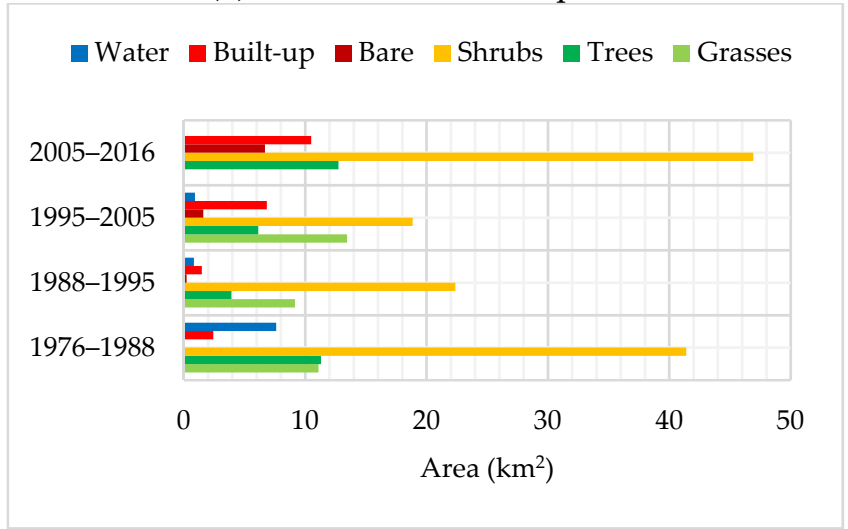

(c) Transition from trees

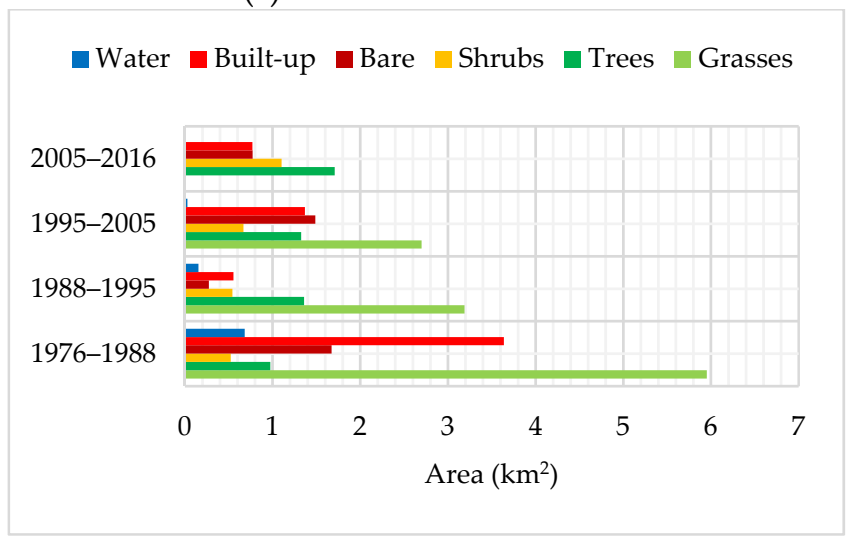

(e) Transition from bare $\square$ Water $\square$ Built-up $\square$ Bare $\square$ Shrubs $\square$ Trees $\square$ Cropland

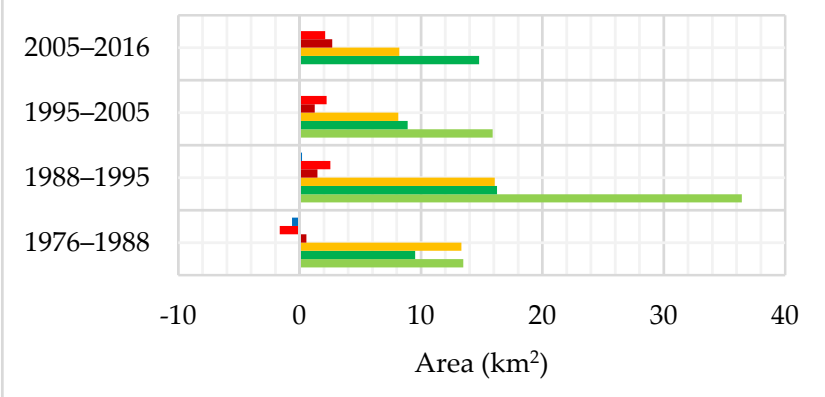

(b) Transition from grasses

$\square$ Water $\square$ Built-up $\square$ Bare $\square$ Shrubs $\square$ Trees $\square$ Grasses

2005-2016

1995-2005

1988-1995

$1976-1988$

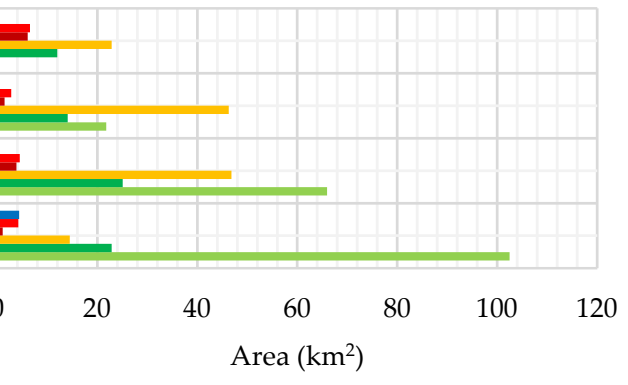

(d) Transition from shrubs

$\square$ Water $\square$ Bare $\square$ Shrubs $\square$ Trees $\square$ Grasses $\square$ Agriculture

2005-2016

1995-2005

1988-1995

1976-1988

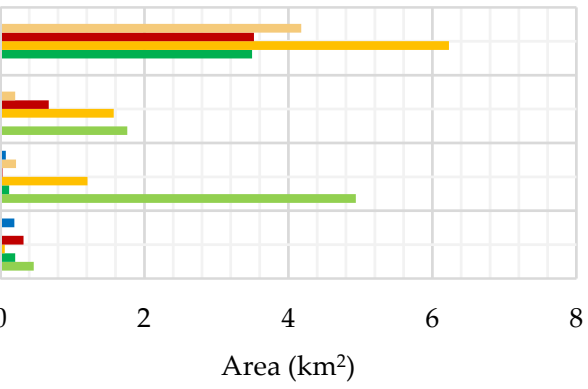

(f) Transition from built-up

Figure 10. Cont. 


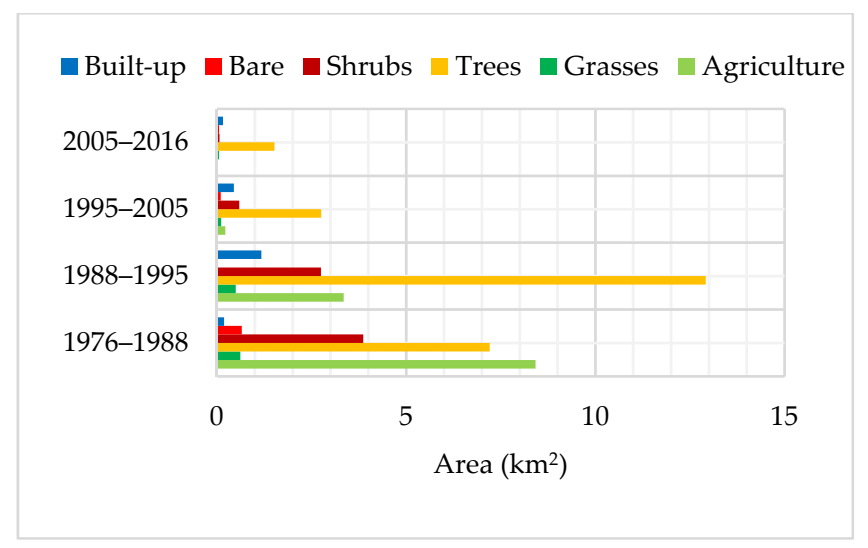

(g) Transition from water

Figure 10. Graphs depicting temporal oscillations concerning interclass transitions among the selected categories of LULC from 1976 to 2016.

\section{Discussion}

The magnitude and speed of urbanization in Pakistan [64] have caused land and environmental degradations in urban areas [23,24]. The scenario entails comprehending the dynamics of urbanization and identifying resultant impacts on the urban land cover of Pakistan. It requires conclusive assessments based on spatial-temporal transformations in the LULCs of urban areas. For this purpose, the current investigation was designed to evaluate the impacts of urbanization on the selected LULC categories of planned and semiplanned (Table 2) urban centers.

The study primarily focuses on the LULC changes that occurred during the selected time intervals from 1976 to 2016. During this time span (1976-2016), these cities witnessed population growth (Appendix A), massive urban sprawl [24] and concomitant LULC transformations $[65,66]$. The accompanying pressures triggered planned and unplanned modifications in the LULC of these urban centers. The findings (Table 3) maintain that the proportion of the built-up areas in these cities was significantly enlarged, while the share of cropland areas declined during this period. These observations substantiate the reported assertions [67-70] pertaining to the impacts of urbanization on the LULC patterns in urban areas. These assessments also authenticate the reported observations $[32,69]$ that the land covers in the twin cities are still transforming due to urbanization. The findings reveal that urban expansions in Rawalpindi followed the pattern of the concentric zone model, which E. W. Burgess proposed in 1923 (https://transportgeography.org/?page_id=4908; Accessed on 15 December 2016) [71].

The model postulates that urban settlements expand outward from a central location (CBD) similar to the growth rings of a tree (Figure 10). The similar nature of urban sprawl is observable in the areas which fall in the administrative jurisdictions of Rawalpindi city. However, the urban expansions in Islamabad are more closely associated with the multiple nuclei model postulated by C. D. Harris and E. L. Ullman in 1945. This model asserts that the heterogeneous nature of socioeconomic activities in urban areas requires specialized location. Islamabad, as the capital city, was designed to cater to diverse socioeconomic needs and functional complexities. These orientations are embedded in urban planning and drive the regulatory control of land resources in Islamabad. Thus, the phenomenon of urban expansion is gaining stimulus from segregated nuclei in this city.

The phenomenal increase in the proportion of built-up surfaces (Table 3 ) in recent years (2005-2016) reflects the cumulative impacts of population growth $[72,73]$ and socioeconomic restructuring of society in Pakistan [74] due to the consequential impacts of wars against terrorism. The precarious security environment in and around the adjoining areas of Khyber Pakhtunkhwa (KPK) forced their populace to migrate [75]. A substantial proportion of these migrants subsequently settled in the study area. Resultantly, the rental and real estate value of property increased. The land developers, in connivance with the local 
administration and real estate agents, encroached on the productive agricultural land and converted it into built-up surfaces. For this purpose, they promoted the lifestyle of 'gated communities' in the outskirts of the study area. The concomitant socioecological complexities associated with urban densification compelled the resourceful residents to move to these newly introduced gated localities [76]. The private sector initially focused on barren/nonproductive agricultural lands due to their low market value. However, for attracting potential buyers, they focused on planned urban greenery and encouraged tree plantations within their jurisdictions. It is evident by the fact that, despite all pressures for land conversions, the proportional share of urban trees and forestry increased in the study area (Figure 10). It transpired that awareness regarding environmental sustainability productively contributed towards ecological resilience. However, increases in the shares of bare soil/rocks (Figure 10) were also due to investments in the housing sector for anticipated profits from real estate transactions. Land developers converted productive land into residential plots, but on most of those plots, houses have not yet been built. The scenario entails stringent regulatory control for the sustainability of land resources in the study area.

While the resourceful migrants preferred to stay in Islamabad, the less resourceful strove to find an abode in Rawalpindi. Resultantly, low-income residential localities in and around Rawalpindi city, such as Pandora, the surrounding areas of Benazir Bhutto international airport, etc., emerged and expanded. The spatial settings of these unregulated intrusions corroborate the notions that low-income groups prefer to live in the vicinity of economic opportunities [77]. In the absence of a coherent housing policy, these individual-driven land cover transformations filled the gap and promoted the phenomenon of unplanned urban development in Rawalpindi. Despite such pressures, the LULC transformations in the municipal limits of Islamabad were carried out according to the master plan. These observations validate the reported assertions that clarity in policy and efficiency in management are obligatory for the sustainability of urban land resources [23,24].

The findings (Table 3) and illustrations (Figure 10) also infer about substantial increases in the proportions of cropland and trees/forested areas during 1988-1995. The increasing demand and high prices of vegetables in twin cities due to population growth (Appendix A) seem to be the plausible cause that motivated the farming communities to convert the shrubby areas into farming lands. The provisioning of agricultural machinery for land management by the Agency for Barani (rain-fed areas) Area Development (ABAD) facilitated such conversions. In addition to this, the awareness emanating through the Arid Agricultural University in Rawalpindi also contributed to these transformations. Consequently, agricultural land expanded in the cities which were previously dominated by natural grass, shrubby and herbaceous land covers. These observations infer that access to technology and awareness suggestively influence the speed and scale of LULC changes. During this time span, the share of tree covers also increased (Table 3). During this time period, an independent Ministry of Environment at the federal level was established [78]. The ministry facilitated efforts for promoting awareness regarding ecological resources. As a result, the efforts for enhanced cooperation with donor agencies and multinational entities ensued. The local governments, specifically the Capital Development Authority (CDA), benefited from such newfound opportunities. Consequently, the portion of green areas increased in Islamabad and Rawalpindi.

\section{Conclusions}

The findings formulate that people in developing countries are drifting towards big urban centers to explore better socioeconomic prospects. This exodus stimulates horizontal expansions, triggers LULC changes and encourages vertical growth and urban densification. Consequently, the land and environmental resources in urban areas are straining. The study reveals that such processes are more predictable, manageable and controlled in planned cities compared to semiplanned cities. The differences are attributable to land use planning and regulatory frameworks. The findings imply that improved regulatory 
supervision, clarity in land use policies and integrated management of land resources are vital for resilient urban growth.

The scenario calls for socioeconomic uplifts in rural areas to curtail the inflow of migrants in big urban settlements such as Islamabad and Rawalpindi. Population control appears to be the most dependable strategy to address such formidable challenges in the developing regions. In addition to this, the findings also stress decentralization of administrative power and improved availability of life services in small-scaled settlements. The measures would curtail pressures on urban land resources in developing regions. The study also authenticates the robustness of remotely sensed data and GIS-based techniques as efficient and cost-effective tools for informed decision making about urban land resources. However, further studies are needed to ascertain the cumulative impacts of ensuing demographic changes and LULC transformations on the resilience of the natural environment in this contextual setting.

Author Contributions: Conceptualization, S.A.B. and Z.S.; methodology, S.A.B., A.A. and M.S.; software, M.Z.-u.-H., S.N. and A.I.; validation, H.H. and A.I.; formal analysis, S.A.B. and M.Z.-u.H.; investigation, S.A.B., S.A. and M.Z.-u.-H.; resources and data curation, M.Z.-u.-H. and M.S.; writing — original draft preparation, S.A.B. and A.A.; writing—review and editing, Z.S., M.S. and S.A.; visualization, M.Z.-u.-H. and S.N.; supervision, Z.S., M.S. and H.H., project administration, S.A.B. and A.I. All authors have read and agreed to the published version of the manuscript.

Funding: The authors thank the Natural Sciences and Engineering Research Council of Canada (NSERC) and the New Brunswick Innovation Foundation (NBIF) for the financial support of the global project. These granting agencies did not contribute to the design of the study or the collection, analysis and interpretation of data.

Institutional Review Board Statement: Not applicable.

Informed Consent Statement: Not applicable.

Data Availability Statement: Not applicable.

Conflicts of Interest: The authors declare no conflict of interest.

\section{Appendix A}

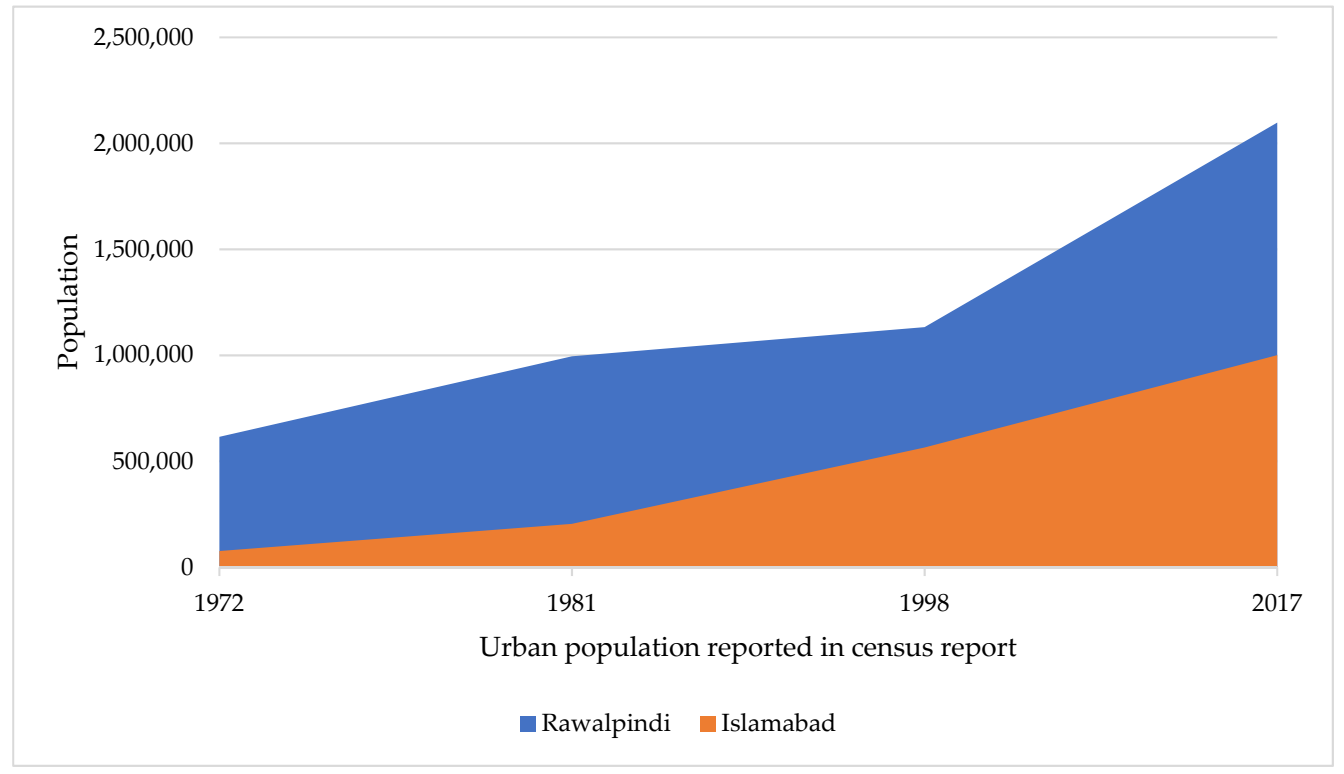

Figure A1. Urban Population of Islamabad and Rawalpindi. 


\section{Appendix B}

Table A1. Accuracy Assessment.

\begin{tabular}{|c|c|c|c|c|c|c|c|c|c|c|c|c|c|c|c|}
\hline \multicolumn{16}{|c|}{ Characteristics and References of Satellite Images Used and Accuracies } \\
\hline & \multicolumn{5}{|c|}{1972} & \multicolumn{5}{|c|}{1988} & \multicolumn{5}{|c|}{1995} \\
\hline $\begin{array}{c}\text { Classified in } \\
\text { Satellite Image as }\end{array}$ & 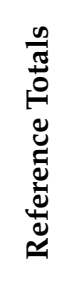 & 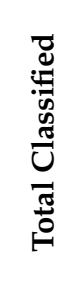 & 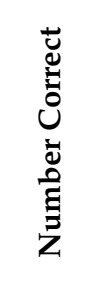 & 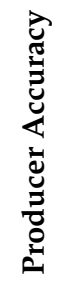 & 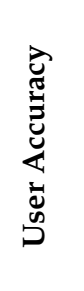 & 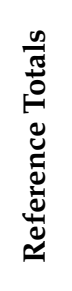 & 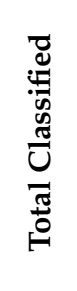 & 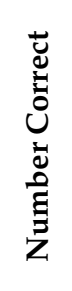 & 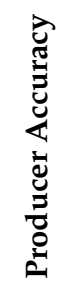 & 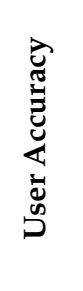 & 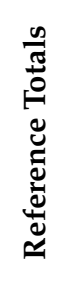 & 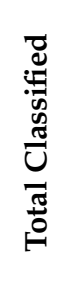 & 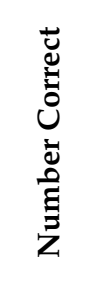 & 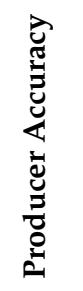 & 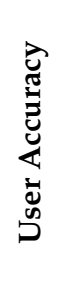 \\
\hline Cropland & 54 & 53 & 48 & 88.9 & 90.6 & 51 & 49 & 43 & 84.3 & 87.8 & 51 & 48 & 45 & 88.2 & 93.8 \\
\hline Grasses & 55 & 50 & 50 & 90.9 & 100 & 54 & 51 & 44 & 81.5 & 86.3 & 55 & 53 & 49 & 89.1 & 92.5 \\
\hline Tree/Forest & 52 & 54 & 49 & 94.2 & 90.7 & 50 & 50 & 43 & 86.0 & 86.0 & 52 & 51 & 45 & 86.5 & 88.2 \\
\hline Shrubs/Tall herbs & 50 & 51 & 50 & 100 & 98 & 54 & 52 & 46 & 85.2 & 88.5 & 51 & 50 & 43 & 84.3 & 86.0 \\
\hline Bare soil/rocks & 54 & 53 & 50 & 92.6 & 94.3 & 54 & 53 & 42 & 77.8 & 79.2 & 50 & 52 & 42 & 84.0 & 80.8 \\
\hline Built-up & 54 & 55 & 49 & 90.7 & 89.1 & 51 & 54 & 43 & 84.3 & 79.6 & 52 & 55 & 49 & 94.2 & 89.1 \\
\hline Water & 51 & 54 & 43 & 84.3 & 79.6 & 50 & 55 & 44 & 88.0 & 80.0 & 52 & 54 & 50 & 96.2 & 92.6 \\
\hline Total & 370 & 370 & 339 & & & 364 & 364 & 305 & & & 363 & 363 & 323 & & \\
\hline \multirow{3}{*}{$\begin{array}{c}\text { Overall Accuracy } \\
\text { Overall Kappa } \\
\text { Statistics }\end{array}$} & \multicolumn{5}{|c|}{$91.6 \%$} & \multicolumn{5}{|c|}{$83.8 \%$} & \multicolumn{5}{|c|}{$89 \%$} \\
\hline & \multicolumn{5}{|c|}{0.8172} & \multicolumn{5}{|c|}{0.6963} & \multicolumn{5}{|c|}{0.7743} \\
\hline & \multicolumn{5}{|c|}{2005} & \multicolumn{5}{|c|}{2016} & & & & & \\
\hline $\begin{array}{l}\text { Classified in } \\
\text { Satellite Image as }\end{array}$ & 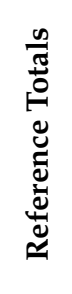 & 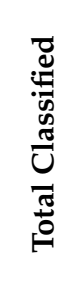 & 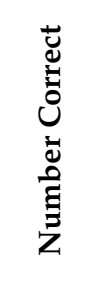 & 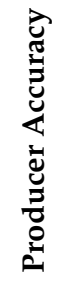 & 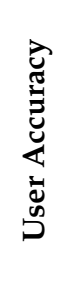 & 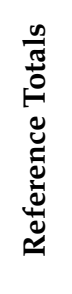 & 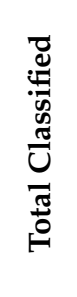 & 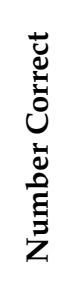 & 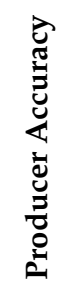 & 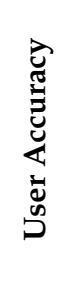 & & & & & \\
\hline Cropland & 54 & 52 & 48 & 88.9 & 92.3 & 50 & 50 & 42 & 84.0 & 84.0 & & & & & \\
\hline Grasses & 53 & 55 & 51 & 96.2 & 92.7 & 51 & 51 & 43 & 84.3 & 84.3 & & & & & \\
\hline Tree/Forest & 52 & 52 & 48 & 92.3 & 92.3 & 54 & 56 & 48 & 88.9 & 85.7 & & & & & \\
\hline Shrubs/Tall herbs & 53 & 54 & 52 & 98.1 & 96.3 & 52 & 53 & 50 & 96.2 & 94.3 & & & & & \\
\hline Bare soil/rocks & 55 & 54 & 49 & 89.1 & 90.7 & 55 & 53 & 42 & 76.4 & 79.2 & & & & & \\
\hline Built-up & 53 & 52 & 46 & 86.8 & 88.5 & 53 & 50 & 44 & 83.0 & 88.0 & & & & & \\
\hline Water & 51 & 52 & 48 & 94.1 & 92.3 & 52 & 54 & 44 & 84.6 & 81.5 & & & & & \\
\hline Total & 371 & 371 & 342 & & & 367 & 367 & 313 & & & & & & & \\
\hline Overall Accuracy & & & $92.2 \%$ & & & & & 85.3 & & & & & & & \\
\hline $\begin{array}{c}\text { Overall Kappa } \\
\text { Statistics }\end{array}$ & & & 0.8933 & & & & & 0.7 & & & & & & & \\
\hline
\end{tabular}

\section{References}

1. De Groot, R.S.; Wilson, M.A.; Boumans, R.M. A typology for the classification, description and valuation of ecosystem functions, goods and services. Ecol. Econ. 2002, 41, 393-408. [CrossRef]

2. Rimal, B.; Zhang, L.; Stork, N.; Sloan, S.; Rijal, S. Urban Expansion Occurred at the Expense of Agricultural Lands in the Tarai Region of Nepal from 1989 to 2016. Sustainability 2018, 10, 1341. [CrossRef]

3. Zaman-Ul-Haq, M.; Saqib, Z.; Kanwal, A.; Naseer, S.; Shafiq, M.; Akhtar, N.; Bokhari, S.A.; Irshad, A.; Hamam, H. The Trajectories, Trends, and Opportunities for Assessing Urban Ecosystem Services: A Systematic Review of Geospatial Methods. Sustainability 2022, 14, 1471. [CrossRef]

4. Ali, L.; Wang, C.; Ullah, I.; Yousaf, A.; Khan, W.U.; Ullah, S.; Khan, R.; Alassery, F.; Hamam, H.; Shafiq, M. Design and Optimization of Microwave Sensor for the Non-Contact Measurement of Pure Dielectric Materials. Electronics 2021, 10, 3057. [CrossRef] 
5. Du, X.; Huang, Z. Ecological and environmental effects of land use change in rapid urbanization: The case of hangzhou, China. Ecol. Indic. 2017, 81, 243-251. [CrossRef]

6. Metzger, M.J.; Rounsevell, M.; Acosta-Michlik, L.; Leemans, R.; Schröter, D. The vulnerability of ecosystem services to land use change. Agric. Ecosyst. Environ. 2006, 114, 69-85. [CrossRef]

7. Larondelle, N.; Frantzeskaki, N.; Haase, D. Mapping transition potential with stakeholder- and policy-driven scenarios in Rotterdam City. Ecol. Indic. 2016, 70, 630-643. [CrossRef]

8. Saarela, S.-R.; Rinne, J. Knowledge brokering and boundary work for ecosystem service indicators. An urban case study in Finland. Ecol. Indic. 2016, 61, 49-62. [CrossRef]

9. Appiah, D.O.; Forkuo, E.K.; Bugri, J.T.; Apreku, T.O. Geospatial Analysis of Land Use and Land Cover Transitions from 1986-2014 in a Peri-Urban Ghana. Geosciences 2017, 7, 125. [CrossRef]

10. Ahern, J.; Cilliers, S.; Niemelä, J. The concept of ecosystem services in adaptive urban planning and design: A framework for supporting innovation. Landsc. Urban. Plan. 2014, 125, 254-259. [CrossRef]

11. Cohen, B. Urbanization in developing countries: Current trends, future projections, and key challenges for sustainability. Technol. Soc. 2006, 28, 63-80. [CrossRef]

12. Vasenev, V.I.; Yaroslavtsev, A.; Vasenev, I.I.; Demina, S.A.; Dovltetyarova, E.A. Land-Use Change in New Moscow: First Outcomes after Five Years of Urbanization. Geogr. Environ. Sustain. 2019, 12, 24-34. [CrossRef]

13. UNDP. "Human Development Reports". The 2016 Global Multidimensional Poverty Index (MPI). 2018. Available online: https:/ /hdr.undp.org/en/2020-MPI (accessed on 1 December 2021).

14. Kugelman, M. Pakistan's Runaway Urbanization: What Can Be Done? Wilson Center: Washington, DC, USA, 2014.

15. Arif, G.; Hamid, S. Urbanization, city growth and quality of life in Pakistan. Eur. J. Soc. Sci. 2009, 10, 196-215.

16. Farah, N.; Zafar, M.I.; Nawaz, N. Socio-Economic and Cultural Factors Affecting Migration Behavior in District Faisalabad, Pakistan. Pak. J. Life Soc. Sci. 2012, 10, 28-32.

17. Safder, Q.; Babar, U. Assessment of Urbanization and Urban Sprawl Analysis through Remote Sensing and GIS: A Case Study of Faisalabad, Punjab Pakistan. Int. J. Acad. Res. Bus. Soc. Sci. 2019, 9, 16-36. [CrossRef]

18. Lopes, N.V.M.; Farooq, S. Smart City Governance Model for Pakistan. Smart Governance for Cities: Perspectives and Experiences; Springer International Publishing: New York, NY, USA, 2020; pp. 17-28.

19. Gilani, H.; Ahmad, S.; Qazi, W.A.; Abubakar, S.M.; Khalid, M. Monitoring of Urban Landscape Ecology Dynamics of Islamabad Capital Territory (ICT), Pakistan, Over Four Decades (1976-2016). Land 2020, 9, 123. [CrossRef]

20. Shaheen, A.; Sheng, J.; Arshad, S.; Salam, S.; Hafeez, M. The Dynamic Linkage between Income, Energy Consumption, Urbanization and Carbon Emissions in Pakistan. Pol. J. Environ. Stud. 2019, 29, 267-276. [CrossRef]

21. Nisar, A.; Akram, A.; Hussain, H. Determinants of internal migration in Pakistan. J. Commer. 2013, 5, 32.

22. Zaman, H.M.; Saqib, Z.; Bokhari, A.S.; Akhtar, N.; Amir, S. The Dynamics Of Urbanizations And Concomitant Land Use Land Cover Transformations In Planned And Quasi-Planned Urban Settlements Of Pakistan. Geogr. Environ. Sustain. 2020, 13, 107-120. [CrossRef]

23. Atif, S.; Saqib, Z.; Ali, A.; Zaman, M.; Akhtar, N.; Fatima, H.; Atif, M.; Farooqi, S. Identification of key-trends and evaluation of contemporary research regarding urban ecosystem services: A path towards socio-ecological sustainability of urban areas. Appl. Ecol. Environ. Res. 2018, 16, 3545-3581. [CrossRef]

24. Atif, S.B.; Saqib, Z.; Ali, A.; Zaman, M.H. The impacts of socio-economic factors on the perception of residents about urban vegetation: A comparative study of planned versus semi-planned cities of Islamabad and Rawalpindi, Pakistan. Appl. Ecol. Environ. Res. 2018, 16, 4265-4287. [CrossRef]

25. La Rosa, D.; Wiesmann, D. Land cover and impervious surface extraction using parametric and non-parametric algorithms from the open-source software R: An application to sustainable urban planning in Sicily. GIScience Remote Sens. 2013, 50, 231-250. [CrossRef]

26. Khalil, R.Z. InSAR coherence-based land cover classification of Okara, Pakistan. Egypt. J. Remote Sens. Space Sci. 2017. [CrossRef]

27. El-Kawy, O.A.; Rød, J.K.; Ismail, H.; Suliman, A. Land use and land cover change detection in the western Nile delta of Egypt using remote sensing data. Appl. Geogr. 2011, 31, 483-494. [CrossRef]

28. Naqvi, H.R.; Siddiqui, L.; Devi, L.M.; Siddiqui, M.A. Landscape transformation analysis employing compound interest formula in the Nun Nadi Watershed, India. Egypt. J. Remote Sens. Space Sci. 2014, 17, 149-157. [CrossRef]

29. Shalaby, A.; Tateishi, R. Remote sensing and GIS for mapping and monitoring land cover and land-use changes in the Northwestern coastal zone of Egypt. Appl. Geogr. 2007, 27, 28-41. [CrossRef]

30. Rawat, J.; Kumar, M. Monitoring land use/cover change using remote sensing and GIS techniques: A case study of Hawalbagh block, district Almora, Uttarakhand, India. Egypt. J. Remote Sens. Space Sci. 2015, 18, 77-84. [CrossRef]

31. Hegazy, I.R.; Kaloop, M.R. Monitoring urban growth and land use change detection with GIS and remote sensing techniques in Daqahlia governorate Egypt. Int. J. Sustain. Built Environ. 2015, 4, 117-124. [CrossRef]

32. Hassan, Z.; Shabbir, R.; Ahmad, S.S.; Malik, A.H.; Aziz, N.; Butt, A.; Erum, S. Dynamics of land use and land cover change (LULCC) using geospatial techniques: A case study of Islamabad Pakistan. SpringerPlus 2016, 5, 1-11. [CrossRef]

33. Butt, A.; Shabbir, R.; Ahmad, S.S.; Aziz, N. Land use change mapping and analysis using Remote Sensing and GIS: A case study of Simly watershed, Islamabad, Pakistan. Egypt. J. Remote Sens. Space Sci. 2015, 18, 251-259. [CrossRef] 
34. Shah, A.; Ali, K.; Nizami, M. Four Decade Land Degradation in Capital City of Islamabad Pakistan during 2017-2019-A Comparative Assessment. Authorea 2020. [CrossRef]

35. Climate-Data.org. Rawalpindi, Pakistan. Available online: https://en.climate-data.org/asia/pakistan/punjab/rawalpindi-1009 /\#climate-graph (accessed on 16 August 2018).

36. Rasul, G.; Sixiong, Z.; Qingcun, Z. A diagnostic study of record heavy rain in twin cities Islāmābad-Rāwalpindi. Adv. Atmos. Sci. 2004, 21, 976-988. [CrossRef]

37. Köppen, W.; Volken, E.; Brönnimann, S. The thermal zones of the earth according to the duration of hot, moderate and cold periods and to the impact of heat on the organic world (Translated from: Die Wärmezonen der Erde, nach der Dauer der heissen, gemässigten und kalten Zeit und nach der Wirkung der Wärme auf die organische Welt betrachtet, Meteorol Z 1884, 1, 215-226). Meteorol. Z. 2011, 20, 351-360.

38. Hussain, S.; Xianfang, S.; Hussain, I.; Jianrong, L.; Mei, H.D.; Hu, Y.L.; Huang, W. Controlling Factors of the Stable Isotope Composition in the Precipitation of Islamabad, Pakistan. Adv. Meteorol. 2015, 2015, 817513. [CrossRef]

39. Amir, S.; Saqib, Z.; Khan, M.I.; Khan, M.A.; Bokhari, S.A.; Zaman-ul-Haq, M.; Majid, A. Farmers' perceptions and adaptation practices to climate change in rain-fed area: A case study from district Chakwal, Pakistan. Pak. J. Agric. Sci. 2020, 57, 465-475.

40. Maria, S.I.; Imran, M. Planning of Islamabad and Rawalpindi: What Went Wrong. 2009. Available online: http:/ / www.isocarp. net/Data/case_studies/720.pdf (accessed on 1 December 2021).

41. Ruback, R.B.; Begum, H.A.; Tariq, N.; Kamal, A.; Pandey, J. Reactions to environmental stressors: Gender differences in the slums of Dhaka and Islamabad. J. Cross-Cult. Psychol. 2002, 33, 100-119. [CrossRef]

42. Shetty, S. Analysis of Machine Learning Classifiers for LULC Classification on Google Earth Engine. Master's Thesis, University of Twente, Enschede, The Netherlands, March 2019.

43. Pimple, U.; Simonetti, D.; Sitthi, A.; Pungkul, S.; Leadprathom, K.; Skupek, H.; Som-Ard, J.; Gond, V.; Towprayoon, S. Google Earth Engine Based Three Decadal Landsat Imagery Analysis for Mapping of Mangrove Forests and Its Surroundings in the Trat Province of Thailand. J. Comput. Commun. 2018, 6, 247-264. [CrossRef]

44. Pimple, U.; Sitthi, A.; Simonetti, D.; Pungkul, S.; Leadprathom, K.; Chidthaisong, A. Topographic Correction of Landsat TM-5 and Landsat OLI-8 Imagery to Improve the Performance of Forest Classification in the Mountainous Terrain of Northeast Thailand. Sustainability 2017, 9, 258. [CrossRef]

45. Olofsson, P.; Foody, G.M.; Herold, M.; Stehman, S.V.; Woodcock, C.E.; Wulder, M.A. Good practices for estimating area and assessing accuracy of land change. Remote Sens. Environ. 2014, 148, 42-57. [CrossRef]

46. Map Accuracy Assessment and Area Estimation. In A Practical Guide; FAO: Roma, Italy, 2016; 69p.

47. Kolios, S.; Stylios, C.D. Identification of land cover/land use changes in the greater area of the Preveza peninsula in Greece using Landsat satellite data. Appl. Geogr. 2013, 40, 150-160. [CrossRef]

48. Scaramuzza, P.L.; Bouchard, M.; Dwyer, J. Development of the Landsat Data Continuity Mission Cloud-Cover Assessment Algorithms. IEEE Trans. Geosci. Remote Sens. 2011, 50, 1140-1154. [CrossRef]

49. Roy, D.P.; Wulder, M.A.; Loveland, T.R.; Woodcock, C.E.; Allen, R.G.; Anderson, M.C.; Helder, D.; Irons, J.R.; Johnson, D.M.; Kennedy, R.; et al. Landsat-8: Science and product vision for terrestrial global change research. Remote Sens. Environ. 2014, 145, 154-172. [CrossRef]

50. Yao, F.; Wang, C.; Dong, D.; Luo, J.; Shen, Z.; Yang, K. High-Resolution Mapping of Urban Surface Water Using ZY-3 Multi-Spectral Imagery. Remote Sens. 2015, 7, 12336-12355. [CrossRef]

51. Haas, J.; Ban, Y. Mapping and Monitoring Urban Ecosystem Services Using Multitemporal High-Resolution Satellite Data. IEEE J. Sel. Top. Appl. Earth Obs. Remote Sens. 2016, 10, 669-680. [CrossRef]

52. Lawrence, R.L.; Wright, A. Rule-based classification systems using classification and regression tree (CART) analysis. Photogramm. Eng. Remote Sens. 2001, 67, 1137-1142.

53. Foody, G.M.; Mathur, A. Toward intelligent training of supervised image classifications: Directing training data acquisition for SVM classification. Remote Sens. Environ. 2004, 93, 107-117. [CrossRef]

54. Shao, Y.; Lunetta, R.S. Comparison of support vector machine, neural network, and CART algorithms for the land-cover classification using limited training data points. ISPRS J. Photogramm. Remote Sens. 2012, 70, 78-87. [CrossRef]

55. Magidi, J.; Nhamo, L.; Mpandeli, S.; Mabhaudhi, T. Application of the Random Forest Classifier to Map Irrigated Areas Using Google Earth Engine. Remote Sens. 2021, 13, 876. [CrossRef]

56. Ma, L.; Liu, Y.; Zhang, X.; Ye, Y.; Yin, G.; Johnson, B.A. Deep learning in remote sensing applications: A meta-analysis and review. ISPRS J. Photogramm. Remote Sens. 2019, 152, 166-177. [CrossRef]

57. Shih, H.-C.; Stow, D.A.; Tsai, Y.H. Guidance on and comparison of machine learning classifiers for Landsat-based land cover and land use mapping. Int. J. Remote Sens. 2018, 40, 1248-1274. [CrossRef]

58. Maxwell, A.E.; Warner, T.A.; Fang, F. Implementation of machine-learning classification in remote sensing: An applied review. Int. J. Remote Sens. 2018, 39, 2784-2817. [CrossRef]

59. Camps-Valls, G.; Benediktsson, J.A.; Bruzzone, L.; Chanussot, J. Introduction to the Issue on Advances in Remote Sensing Image Processing. IEEE J. Sel. Top. Signal. Process. 2011, 5, 365-369. [CrossRef]

60. Pontius Jr, R.G.; Peethambaram, S.; Castella, J.-C. Comparison of three maps at multiple resolutions: A case study of land change simulation in Cho Don District, Vietnam. Ann. Assoc. Am. Geogr. 2011, 101, 45-62. [CrossRef] 
61. Malaviya, S.; Munsi, M.; Oinam, G.; Joshi, P.K. Landscape approach for quantifying land use land cover change (1972-2006) and habitat diversity in a mining area in Central India (Bokaro, Jharkhand). Environ. Monit. Assess. 2009, 170, 215-229. [CrossRef] [PubMed]

62. Gaglio, M.; Aschonitis, V.G.; Gissi, E.; Castaldelli, G.; Fano, E.A. Land use change effects on ecosystem services of river deltas and coastal wetlands: Case study in Volano-Mesola-Goro in Po river delta (Italy). Wetl. Ecol. Manag. 2016, 25, 67-86. [CrossRef]

63. Owojori, A.; Xie, H. Landsat image-based LULC changes of San Antonio, Texas using advanced atmospheric correction and object-oriented image analysis approaches. In Proceedings of the 5th International Symposium on Remote Sensing of Urban Areas, Tempe, AZ, USA, 14-16 March 2005.

64. Qasim, M.; Anees, M.; Ghani, M.; Malik, J.; Khalid, M.; Bashir, A. Environment degradation cause by urbanization in Pakistan (A Review Paper). Bull. Energy Economics. 2014, 2, 62-71.

65. Sohail, M.T.; Mahfooz, Y.; Azam, K.; Yat, Y.; Genfu, L.; Fahad, S. Impacts of urbanization and land cover dynamics on underground water in Islamabad, Pakistan. Desalination Water Treat. 2019, 159, 402-411. [CrossRef]

66. Liu, Y.; Din, S.U.; Jiang, Y. Urban growth sustainability of Islamabad, Pakistan, over the last 3 decades: A perspective based on object-based backdating change detection. GeoJournal 2020, 86, 2035-2055. [CrossRef]

67. Ali, M.; Khan, S.J.; Aslam, I.; Khan, Z. Simulation of the impacts of land-use change on surface runoff of Lai Nullah Basin in Islamabad, Pakistan. Landsc. Urban. Plan. 2011, 102, 271-279. [CrossRef]

68. Adeel, M. Methodology for identifying urban growth potential using land use and population data: A case study of Islamabad Zone IV. Procedia Environ. Sci. 2010, 2, 32-41. [CrossRef]

69. Ali, S.M.; Malik, R.N. Vegetation communities of urban open spaces: Green belts and parks in Islamabad city. Pak. J. Bot 2010, 42, 1031-1039.

70. Adeel, M. The role of Land Use Policy behind unauthorized spatial expansion in rural areas of Islamabad. In Proceedings of the 46th ISOCARP Congress, Nairobi, Kenya, 19-23 September 2010.

71. Meyer, W.B. THE OTHER BURGESS MODEL. Urban. Geogr. 2000, 21, 261-270. [CrossRef]

72. Buhaug, H.; Urdal, H. An urbanization bomb? Population growth and social disorder in cities. Glob. Environ. Chang. 2012, 23, 1-10. [CrossRef]

73. Khan, A.A.; Arshad, S.; Mohsin, M. Population Growth and Its Impact on Urban Expansion: A Case Study of Bahawalpur, Pakistan. Univers. J. Geosci. 2014, 2, 229-241. [CrossRef]

74. Sardar, S. Looming urban sprawl and its implications: An overview of South Asian urbanization. Reg. Stud. 2012, 33, 1-21.

75. Mujeeb, A.; Zubair, A. Resilience, stress, anxiety and depression among internally displaced persons affected by armed conflict. Pak. J. Soc. Clin. Psychol 2012, 9, 20-26.

76. Yaqub, M. Open Source Architecture: Redefining Residential Architecture in Islamabad. Architecture Thesis, Roger Williams University, Bristol, RI, USA, 2017.

77. Malik, S.; Wahid, J. Rapid Urbanization: Problems and Challenges for Adequate Housing in Pakistan. J. Sociol. Soc. Work 2014, 2. [CrossRef]

78. Hassan, J. Environmental Law of Pakistan. Glob. Envtl. L. Ann. 1996, 15. Available online: https://heinonline.org/HOL/ LandingPage?handle=hein.journals / gloenvla4\&div=5\&id=\&page= (accessed on 1 December 2021). 